\title{
Analisis Pengarang Dalam Novel Leftenan Adnan Wira Bangsa Karya Abdul Latip Bin Talib
}

\author{
Noraini Ibrahim, Ani Omar* \\ Fakulti Bahasa dan Komunikasi, Universiti Pendidikan Sultan Idris, Tanjong Malim, Perak Darul Ridzuan 35900, Malaysia. \\ *Corresponding author: ani.omar@fbk.upsi.edu.my
}

\begin{abstract}
This study entitled "Analysis of the Novel Leftenan Adnan Wira Bangsa work Abdul Latip bin Talib" with the objective to study the thinking of the author in his work which is related to the events he undertook as well as though the experiences of other individual that are adapted in this novel. This study uses a local thory of Integrated System theory 4K or short name SPB4K introduced by Mohd Yusof Hasan. This theory is based on the philosophy of unity of thought which is thought thinking, spiritual thingking, scientific thinking and creativity thinking. In addition the study is performed to identify the author's mind and to analyse the author thought using the SPB4K theory. From the research done, it is concluded that all four aspect of thinking are widely used in the novel Leftenan Adnan Wira Bangsa and until now, there is no research done on it. This may due to the fact that this is a 2014 novel and it is just introduced to Form 4 to study for Zone 2 in Malaysia. This research also is expected to pull the author interest to produce more quality literature works and become the compulsory KOMSAS text for schools in Malaysia. Apart from that, this literature can eleviate the nation dignity and become the example to the society.
\end{abstract}

Keywords: Thoughts; spiritual; scientific; creativity

\begin{abstract}
Abstrak
Kajian "Analisis Pemikiran Pengarang dalam Novel Leftenan Adnan Wira Bangsa karya Abdul Latip bin Talib" bertujuan untuk mengkaji pemikiran pengarang dalan karya beliau tentang peristiwa yang dialami daripada diri pengarang sendiri mahupun melalui pengalaman individu lain yang diadaptasi dalam novel ini. Kajian ini menggunakan teori tempatan iaitu Teori Sistem Bersepadu 4K atau Teori SPB4K janaan Mohd Yusof Hasan. Teori ini berteraskan falsafah kesepaduan pemikiran iaitu Pemikiran Kerohanian, Pemikiran Kebitaraan, Pemikiran Kesaintifikan dan Pemikiran Kekreatifan. Objektif kajian ini dilakukan untuk mengenal pasti pemikiran pengarang novel ini dan menganalisis pemikiran pengarang ini menggunakan teori SPB4K. Dapatan kajian mendapati, keempat-empat aspek pemikiran ini terkandung dalam Novel Leftenan Adnan Wira Bangsa yang digarap secara terperinci dan sehingga kini masih belum terdapat mana-mana pengkaji yang membuat kajian ilmiah terhadap novel ini. Hal ini kerana novel terbitan 2014 ini merupakan novel terbaharu untuk kajian pelajar-pelajar tingkatan 4 bagi zone 2 di Malaysia. Pengkajian ini juga diharapkan dapat menarik minat penulis untuk menghasilkan lebih banyak karya sastera yang bermutu dan dapat dijadikan sebagai teks KOMSAS wajid di sekolah-sekolah Malaysia. Di samping itu, karya sastera ini diharapkan berjaya mengangkat martabat wira bangsa agar menjadi suri teladan kepada masyarakat pembaca.
\end{abstract}

Kata Kunci: Pemikiran; kerohanian; kebitaraan; kesaintifikan; kekreatifan

(C) 2017 Penerbit UTM Press. All rights reserved

\subsection{PENGENALAN}

Sebuah karya kreatif merupakan sebuah wadah yang digunakan oleh pengarang untuk menyalurkan pendapat dan pemikirannya kepada masyarakat. Pemikiran dan pendapat tersebut disampaikan melalui peranan watak sehingga membawa kepada perkembangan sebuah cerita yang dihasilkan dengan pelbagai teknik penceritaan. Umumnya, pemikiran menurut Mohd Yusof Othman (1998:59) mempunyai pengertian yang luas dan boleh diterangkan dalam pelbagai pendekatan. Namun, berfikir merupakan suatu usaha untuk meningkatkan pengetahuan seseorang. Kemampuan dan keluasan berfikir tidak akan menjadikan seseorang itu stereotaip dalam tindakan dan amalannya.

\section{1..Latar Belakang Kajian}

Penggemar novel hari ini kurang mengutamakan aspek penghayatan tetapi keseronokan semata-mata. Keadaan ini menyebabkan pembaca tidak memahami dan mengetahui aspek pemikiran yang hendak di ketengahkan oleh pengarang dalam sesebuah novel. Pembaca biasanya memfokuskan jalinan cerita daripada pemikiran pengarang. Ani Hj Omar (2016:3) dalam kajian buku Sastera Remaja di Malaysia menyatakan bahawa menjelang wawasan 2020 negara perlukan golongan berilmu dan pemikir yang berkarya untuk melahirkan generasi muda khususnya golongan remaja yang progresif dan dinamik. Konsep pemikiran pernah dijelaskan oleh Zainal Kling (1993 :400) sebagai kegiatan untuk membentuk sesuatu ocial tanggapan yang akan menjadi rangka berfikir yang wajar bagi semua anggota masyarakat.Oleh yang demikian hanya orang yang mampu berfikir boleh melakukan perubahan dan boleh menjana aktiviti yang bersifat 
kreatif dan membangun. Kekuatan sesebuah novel tidak hanya terpamer dalam diri pengarang, tetapi juga bergantung kepada sejauh mana novel itu dimanfaatkan sebagai bahan untuk memperkasa ilmu pengetahuan kepada pembaca.

Pemikiran kreatif bermaksud menggunakan akal fikiran untuk menjana idea dan menghasilkan sesuatu yang baru atau sesuatu yang luar biasa sama ada maujud atau abstrak. Siti Khariah Mohad Zubir (2008:75) mentakrifkan bahawa pemikiran kreatif sebagai suatu pemikiran yang berkemampuan mencipta sesuatu yang baharu. Pemikiran merupakan proses menggunakan akal fikiran atau minda untuk menghasilkan sesuatu perkara atau menyelesaikan dalam pelbagai aspek kehidupan manusia. Siti Emy Nor Shafeena Mohd Sain (2013:3) menjelaskan bahawa pemikiran kreatif pengarang ditulis berdasarkan suasana yang menarik perhatian pembaca. Namun, ramai dalam kalangan pembaca novel tidak mengutamakan aspek penghayatan tetapi hanya untuk keseronokan sahaja. Keadaan ini menyebabkan pembaca tidak memahami dan mengetahui aspek pemikiran yang hendak diketengahkan oleh pengarang dalam sesebuah novel. Apa yang sering kali dilakukan oleh pembaca ialah mereka lebih menumpukan plot cerita atau jalinan cerita daripada pemikiran pengarang. Pembaca lebih tertarik untuk mengetahui apakah konflik yang berlaku pada watak, mengetahui jalan penyelesaian terhadap konflik yang berlaku serta ingin mengetahui kesudahan cerita yang membawa kepada pengakhiran sesebuah cerita. Menurut Naffi Mat (2013:226) turut memberi pendapat pemikiran penyair dalam puisi-puisi Pemikiran Dharmawijaya mempunyai keupayaan sebagai satu wahana untuk memperlihatkan mesej seni yang kaya dengan nilai estetika.

Mohd Yusof Md Nor \& Inon Shahharuddin Abdul Rahman (1992:xiii) turut memberi pendapat tentang nilai-nilai baik yang terkandung dalam sesuatu hasil karya penulis seperti berikut:

kesusasteraan adalah karya ciptaan yang menyatakan pengalaman dan perasaan manusia. Di dalamnya terkandung gambaran nilai hidup masyarakatnya. Karya-karya yang dihasilkan mengandung unsur-unsur moral, pendidikan dan nilai hormat menghormati, nilai kemanusiaan, taat setia, kejujuran dan berbagaibagai lagi.

Nor Raudah Hj Siren: (2006:ix) menyatakan kesusasteraan remaja merupakan wahana yang amat penting dalam usaha dan upaya untuk mengisi sebahagian daripada tuntutan keperluan remaja, terutamanya daripada segi pengisian minda, pembentukan sahsiah, kerohanian dan pemantapan psikologi. Sastera remaja, terutamanya novel merupakan antara bahan bacaan yang mampu membangunkan minda remaja sesuai dengan usia mereka yang perlu diberi kebebasan tetapi dalam pengawasan dan bimbingan orang tua mereka. Ini bermakna daripada pembacaan novel ini dijangka mampu membantu ibu bapa ocial kemenjadian generasi remaja yang ocial dan cemerlang. Sesebuah karya kreatif merupakan sebuah wadah yang digunakan oleh pengarang untuk menyalurkan pendapat dan pemikirannya kepada masyarakat. Pemikiran dan pendapat tersebut digarapkan melalui peranan watak-watak sehingga membawa kepada perkembangan sesebuah cerita yang dihasilkan dengan pelbagai teknik naratif. Namun untuk menggambarkan sesebuah masyarakat yang telah maju, ia masih memerlukan maklumat daripada hasil karya sastera terdahulu untuk memberi pedoman kepada masyarakat kni. Ini kerana Menurut Harun Mat Piah (2006:37) antaranya ialah ia bersifat kolektif dan dianggap milik bersama masyarakat. Oleh itu, kebanyakan karya mementingkan pemilihan tema, watak dan latar bersifat fungsional, iaitu semua karya dicipta berkembang dan dimanfaatkan oleh pembaca dari dahulu hingga kini. Dalam kajian ini, pengkaji mendapati terdapat unsur positif dalam novel untuk membangunkan nilai-nilai kemanusiaan remaja pembaca. Segala keperitan hidup manusia tersebut dijelmakan dalam bentuk nilai masyarakatnya. Hal ini disebabkan manusia pada hari ini mementingkan intelektual sehingga mengabaikan nilai-nilai kemanusiaan yang membawa kepada masyarakat yang materealistik.

Pengertian remaja seperti yang dikemukakan oleh Cooler (1994:6) bahawa masa remaja menunjukkan dengan jelas sifat transisi atau peralihan karana remaja belum memperoleh status dewasa dan tidak lagi memiliki status anak. Menurut Sri Rumini \& Siti Sundari (2004:53) masa remaja adalah peralihan dari masa anak dengan masa dewasa yang mengalami perkembangan semua aspek atau fungsi untuk memasuki masa dewasa. Masa remaja berlangsung antara umur 12 tahun sehingga 21 tahun bagi wanita dan 13 tahun sehingga 22 tahun bagi lelaki. Sedangkan pengertian remaja menurut Zakiah Darajat (1990: 23) adalah:

masa peralihan di antara masa kanak-kanak dan dewasa. Dalam masa ini anak mengalami masa pertumbuhan dan masa perkembangan fisiknya maupun perkembangan psikisnya. Mereka bukanlah anakanak baik bentuk badan ataupun cara berfikir atau bertindak, tetapi bukan pula orang dewasa yang telah matang.

Hal senada diungkapkan oleh Santrock (2003: 26) bahwa adolescene diertikan sebagai masa perkembangan transisi antara masa anak dan masa dewasa yang mencakup perubahan biologis, kognitif, dan ocial-emosional.

Menariknya sesebuah novel tidak hanya mengetengahkan bakat pengarang, tetapi juga bergantung kepada sejauh mana novel itu dimanfaatkan sebagai bahan yang mampu memperkasakan ilmu pengetahuan dalam usaha pelbagai pihak untuk pembangunan modal insan masyarakat. Novel sebenarnya boleh dijadikan sebagai satu gagasan pendidikan kerana novel banyak memperlihatkan pemikiran pengarang yang peka terhadap citra kehidupan masyarakat dalam zamannya dan berusaha untuk memperbaik taraf kehidupan masyarakat. Dalam kajian ini, pengkaji memilih penulisan kreatif pengarang Abdul Latip bin Talib dalam novel Leftenan Adnan Wira Bangsa yang dianggap dapat mempengaruhi minda dan sikap positif pembacanya. Oleh yang demikian, pembaca khususnya remaja dalam lingkungan usia 16 hingga 18 tahun seharusnya lebih peka dengan pemikiran yang diilhamkan oleh pengarang melalui novel yang terhasil. Hal ini kerana novel ini menjadi bahan kajian kepada semua pelajar tingkatan 4 zon2 iaitu negeri Selangor, Kuala Lumpur.

Dalam kajian ini, pengkaji akan mengkaji tentang pemikiran pengarang novel Leftenan Adnan Wira Bangsa dengan menggunakan teori SPB4K yang dikatakan dapat membangunkan nilai kemanusiaan remaja. Penulisan pengarang yang kreatif merupakan bidang ilmu yang sentiasa berkembang dari semasa ke semasa, sesuai dengan perubahan pemikiran manusia, teknologi dan gaya kreativiti manusia. K.Bertens, (2003:25) berpendapat dalam amalan hidup harian, pegangan nilai kemanusiaan merupakan motivasi terpenting individu. Walau apa perubahan yang berlaku dalam bidang penulisan kreatif, sama ada dari segi teori dan praktik, hanya golongan penulis yang cekal, beriltizam dan serius sahaja yang akan kekal terlibat sebagai penulis. 
Kesimpulannya, berdasarkan isu-isu yang telah dinyatakan inilah, pengkaji merasakan perlu untuk menjalankan kajian dan penelitian berkaitan dengan novel. Pengkaji memilih untuk menelusuri pemikiran pengarang novel Leftenan Adnan Wira Bangsa dengan memberi fokus terhadap kesepaduan empat aspek pemikiran Teori Sistem Pemikiran Bersepadu 4K (SPB4K) yang diperkenalkan oleh Mohd Yusof Hasan. Bukan itu sahaja, pengarang novel ini juga menyerapkan unsur nilai untuk membangunkan nilai kemanusiaan remaja dalam novel ini agar pembangunan modal insan remaja dapat dilaksanakan dengan jayanya. Oleh itu, masyarakat yang berjaya adalah apabila remajanya mempunyai nilai kemanusiaan yang tinggi sebagai benteng dalam diri mereka kerana manusia mempunyai hubungan yang erat

dengan agama dan moral.

\subsection{Penyataan Masalah}

Kajian ini dilakukan untuk meneliti aspek pemikiran yang ditonjolkan oleh Abdul Latib bin Talib dalam bidang penulisan novelnya iaitu Leftenan Adnan Wira Bangsa. Persoalan mengenai pemikiran yang diungkapkan dalam novel adalah menarik untuk dikaji. Hal ini kerana pemikiran merupakan pusat utama dapat dilihat gagasan seseorang penulis memperlihatkan perjuangan mereka menerusi hasil-hasil seninya (Baha Zain, 1991:18-21). Berdsarkan pengkajian lalu tentang kajian pemikiran didapati bahawa tiada pengkaji yang menulis tentang pemikiran pengarang novel Leftenan Adnan Wira Bangsa ini dan hasil penelitian pengkaji karyanya sangat sesuai dalam membangunkan nilai kemanusiaan golongan remaja hari ini sebagai generasi pelapis pemimpin negara pada masa akan datang. Oleh itu, dalam penelitian pengkaji novel ini telah dapat mengenal pasti aspek pemikiran pengarang yang disesuaikan dengan pendekatan teori SPB4K dan keunikan novel ini dalam membangunkan nilai kemanusiaan golongan remaja pembaca hari ini.

\subsection{Kepentingan Kajian}

Penyelidikan ini diharapkan dapat mempelbagaikan corak kajian terhadap sastera Melayu dalam menyingkap pemikiran dan kreativiti pengarang. Masyarakat akan lebih memahami pemikiran yang cuba diungkapkan oleh Abdul Latib bin Talib berdasarkan isu relaiti kehidupan masyarakat umum yang mendokong kepada perkembangan plot novel ini. Selain itu, kajian ini juga penting untuk memperjelaskan kepada pembaca, serta memberi informasi penting tentang sejarah perang dunia kedua yang terakam megah di dalam novel ini. Kajian ini juga penting sebagai wahana pengarang untuk memberi gambaran yang jelas kepada pembaca khususnya generasi kini yang jahil tentang nilai sejarah tanah air. Hasil kajian juga dapat meneliti sejauhmana pengarang ini berjaya membawa kesedaran dari cerminan latar kehidupan dan permasalah masyarakat di luar dalam bentuk novel sebagai tatapan khalayak khususnya golongan remaja pembaca atau pelajar sekolah menengah tingkatan 4.

Harapan pengkaji, kajian ini juga dapat dijadikan landasan oleh pengkritik-pengkritik lain dalam manambah lagi kritikan dalam memartabatkan dan memajukan bidang kesusasteraan tanah air. Penglibatan prngkritik dalam memberikan ulasan dan saranan terutamanya dalam pemikiran akan dapat memartabatkan lagi bidang penulisan novel terutamanya di dalam novel-novel yang dihasilkan oleh pengarang. Maka kajian ini akan memperbanyak khazanah kritikan dan kajian novel. Kajian ini diharapkan dapat menambah kuantiti penulisan kreatif di samping meningkatkan kualiti penghasilan novel di negara ini. Malah diharapkan kajian ini dapat dijadikan satu anjakan paradigma dalam meneliti pemikiran yang masih kurang meluas dikaji. Justeru, kajian ini perlu dilakukan.

\subsection{Objektif Kajian}

Objektif penyelidikan ini adalah bertujuan merungkaikan beberapa perkara tertentu iaitu:

1. Mengenal pasti aspek pemikiran pengarang dalam karya yang dipilih.

2. Menganalisis pemikiran pengarang berdasarkan karya yang dipilih menggunakan teori SPB4K.

\subsection{Soalan Kajian}

Kajian ini akan menjelaskan tentang beberapa persoalan berikut:

1. Apakah aspek pemikiran yang telah dipaparkan oleh pengarang dalam novel yang dipilih.

2. Bagaimana pemikiran pengarang dalam karya yang dipilih dapat dianalisis dengan menggunakan teori SPB4K.

\subsection{Batasan Kajian}

Kajian ini dibataskan kepada novel Lefenan Adnan Wira Bangsa karya Abdul Latib binTalib yang diterbitkan pada tahun 2014 yang mengisahkan peristiwa dalam lipatan sejarah negeri Tanah Melayu yang pernah dijajah oleh pihak Jepun dan pihak Inggeris. Novel ini dipilih berdasarkan keunikan novel sehingga terpilih sebagai teks wajib dikaji oleh pelajar-pelajar tingkatan 4 sekolah menengah bagi zon 2. Pemaparan isu yang dalam novel ini juga sesuai dijadikan bahan kajian untuk tatapan pembaca golongan remaja dan menjadi sumbangan bermutu kepada kesusasteraan tanah air apabila berjaya menghasilkan novel sejarah yang diadaptasi daripada kisah benar atau peristiwa yang berlaku di negara kita. Menurut Rosnah Baharudin (2003:182) pengalaman panit manis kehidupan keluarga Melayu dalam novel Alun Hidup (2000) karya Khatijah Hashim telah menyebabkan Christine Chambell, seorang wanita Australia telah menterjemahkan novel ini ke dalam bahasa Inggeris. Justeru, pengkaji telah mendapati novel Leftenan Adnan Wira bangsa juga sesuai untuk membuka minda pembaca agar menerima novel ini sebagai idea pemikiran pengarang untuk mengubah persepsi masyarakat pembaca ke arah kecemerlangan hidup. 


\subsection{Kaedah Kajian}

Kaedah kajian yang digunakan dalam kajian ini ialah kaedah kepustakaan iaitu kaedah analisis teks atau analisis kandungan teks novel yang dipilih. Kaedah kepustakaan digunakan untuk mendapatkan maklumat yang sesuai serta diperlukan melalui buku, jurnal, kertas kerja, majalah, rencana, makalah, akhbar, penulisan ilmiah dan tesis. Teori Sistem Pemikiran Bersepadu 4K (SPB4K) akan digunakan untuk mengkaji teks Leftenan Adnan Wira Bangsa bagi membantu mengumpulkan sebanyak mungkin maklumat tertentu untuk dijadikan fokus perbincangan serta bahan untuk dianalisis.

\subsection{SOROTAN LITERATUR}

\subsection{Kajian Dalam Negara dan Luar Negara}

Daripada tinjauan yang dilakukan oleh pengkaji, terdapat beberapa kajian yang dilakukan oleh penyelidik dalam mengkaji aspek pemikiran yang cuba diketengahkan oleh pengarang dalam karya. Contohnya, diperingkat Doktor Falsafah, kajian dilakukan oleh Koh Young Hun (1993) dalam tesisnya pada peringkat Ijazah Doktor Falsafah yang bertajuk "Pemikiran Pramoedya Ananta Toer dalam Novel-novel Mutakhirnya" dari Jabatan Pengajian Melayu, Universiti Malaya (UM), Kuala Lumpur memperlihatkan pemikiran Pramoedya dalam Tetralogi Bumi Manusia yang mengambil bentuk novel sejarah untuk memaparkan pemikiran pengarang berdasarkan kepada faktor- faktor sejarah zaman lampau negaranya. Pramoedya mendedahkan di dalam karya bahawa adalah lebih penting untuk memperjelaskan dan menghidupkan fakta sejarah agar tidak luput ditelan zaman. Batasan kajian ini meliputi ruang lingkup pemikirannnya terhadap masalahmasalah berkenaan masa depan masyarakatnya.

Kajian seterusnya dilakukan oleh Hashim Ismail yang bertajuk "Pemikiran Kaum Muda dalam Novel-Novel Sebelum Perang Dunia Kedua." Tesis Doktor Falsafah ini disempurnakan pada tahun 2003 di Universiti Malaya. Dalam kajian ini, Hashim Ismail memperkatakan tentang pemikiran kaum muda yang didokong oleh Syed Sheikh Al-Hadi. Kajian ini juga berasaskan hipotesis bahawa terdapat satu gerakan penulis yang tidak diorganisasikan tetapi mempunyai pengaruh yang besar dalam dunia penulisan novel Melayu sekitar zaman Perang Dunia Kedua. Kajian ini menggunakan pendekatan Hermenutic.

Kajian selanjutnya Masrizayu Mustafa (2006) dalam kajiannya yang bertajuk "Pemikiran dalam Novel-novel Khadijah Hashim" mendapati bahawa kajian yang dijalankan merangkumi aspek sosiobudaya, sosiopolitik, dan sosioekonomi. Pengkaji telah menganalisis 10 buah novel Khadijah Hashim dengan menggunakan pendekatan sosiologi sastera. Aspek-aspek ini diteliti oleh pengkaji untuk melihat perkaitan pemikiran penulis dengan masyarakat.

Seterusnya daripada kajian berbentuk kertas kerja yang ditulis oleh Shahnon Ahmad yang berjudul "Pemikiran Dalam Novel Juara." Kertas kerja ini dimuatkan dalam buku Novel-Novel Malaysia dalam Kritikan diselenggarakan oleh Hamzah Hamdani pada tahun 1993. Shahnon Ahmad memperkatakan pemikiran tentang akhlak; kerosakan akhlak segelintir manusia kerana sanggup melakukan apa sahaja untuk mencapai kemenangan sama ada dalam pilihan raya atau laga lembu. Segala tenaga dan semua jenis benda termasuklah pengabaian keluarga dicurahkan bagi menjamin kemenangan.

Dalam kajian yang dijalankan oleh Mahaletchimi A/P Balakrishnan dalam tesis Doktor Falsafahnya di UPSI (2011:iv) bertajuk "Pemikiran Bersepadu 4K Dalam Prosa Melayu Tradisional KOMSAS". Kajian difokuskan untuk memperjelaskan unsur-unsur pemikiran bersepadu $4 \mathrm{~K}$, unsur-unsur pengajaran dan nilai-nilai murni dalam petikan prosa Melayu tradisional KOMSAS dengan mengkaji 20 petikan KOMSAS. Menurut kajian Mahaletchimi, petikan prosa Melayu tradisional mampu menyemai nilai-nilai murni melalui empat pemikiran dengan menitikberatkan pemikiran bersepadu dan penemuan ciri-ciri insan yang yang berakhlak baik.

Sebuah lagi kertas kerja yang ditulis oleh Ani Omar yang bertajuk "Kritikan Novel Cinta Madinah Karya Abu Hassan Morad" dari perspektif Teori SPB4L/4K. Kertas kerja ini dibentangkan dalam Seminar Sasterawan Felda pada bulan Mac 2010 di Universiti Sultan Idris, Tanjung Malim. Kajian novel Cinta Madinah (2004) menerangkan pemikiran pengarang yang membawa erti sebenar cinta manusia kepada Junjungan Besar Nabi Muhammad S.A.W., terutama kepada mereka yang pernah menziarahi makam baginda di Madinah AlMukaramah. Perasaan cinta kepada baginda Rasulullah S.A.W. akan lebih menebal sekiranya kita berada di Madinah dan apabila kita dapat berkunjung ke makam baginda di sana.

Secara keseluruhannya, berdasarkan kajian-kajian lepas telah banyak pengkaji membuat kajian berkaitan dengan novel. Semua kajian ini adalah berkaitan dengan pemikiran dan isu atau pemasalahan yang terdapat dalam novel yang terpilih. Setiap pemikiran dan isu yang diutarakan adalah berbeza mengikut keutamaan dan dominasi yang wujud di dalam novel tersebut. Pemikiran dan isu yang menjadi pasak dalam sesebuah novel akan menjadikan sesebuah karya itu lebih bernilai kerana di dalamnya terkadung pelbagai ilmu dan menjadi utusan kepada pembaca. Masyarakat pembaca seharusnya lebih peka dengan pemikiran yang diilhamkan oleh pengarang novel ini melalui konsep teori Sistem Pemikiran Bersepadu 4K (SPB4K), bukan setakat pemikiran soal cinta, novel ini juga padat dengan pemikiran kebitaraan, pemikiran kesaintifikan dan pemikiran kekreatifan. Oleh itu, kajian ini meneroka pemikiran Abdul Latip bin Talib dalah karya Leftenan Adnan Wira Bangsa yang berkisar tentang cinta akan tanah air yang seharusnya ada pada setiap rakyat Malaysia khususnya golongan remaja.

\subsection{METODOLOGI KAJIAN}

\subsection{Teori Sistem Pemikiran Bersepadu (SPB4K)}

Teori Sistem Pemikiran Bersepadu pada awalnya dikenali sebagai Teori SPB4L diperkenalkan oleh Mohd Yusof Hasan seorang tokoh pemikir dan sarjana dari Universiti Pendidikan Sultan Idris (UPSI). Teori SPB4K berteraskan kepada falsafah kesepaduan pemikiran yang merangkumi aspek kesepaduan yang perlu wujud dalam diri setiap individu iaitu pemikiran kerohanian, pemikiran kebitaraan, pemikiran kesaintifikan dan pemikiran kekreatifan. Keempat-empat pemikiran ini mengutamakan amalan secara bersepadu yang perlu wujud dalam diri individu secara seimbang dan bertimbal balik dan bukannya berasingan. Mengikut Mohd Yusof Hasan (2007:1-33) pemikiran 
merupakan satu kegiatan dan proses penggunaan akal manusia untuk pelbagai motif dalam kehidupan. Kepentingan pemikiran adalah untuk mengenali Tuhan dalam kehidupan bagi menyelesaikan masalah serta dapat membuat keputusan demi kesejahteraan dan kebahagiaan hidup manusia.

Pemikiran kerohanian merupakan pemikiran yang suci murni, tinggi darjatnya, kudus sifatnya dan syahdu martabatnya. Ianya berkaitan dengan unsur keagamaan, ketauhidan dan keesaan Tuhan. Pemikiran ini juga menggambarkan falsafah dan kepercayaan manusia serta turut dianggap sebagai pemikiran keimanan. Dalam agama Islam, pemikiran kerohanian memperlihatkan hubungan dan komunikasi manusia secara vertikal, iaitu manusia sebagai hamba sekaligus sebagai khalifah yang berhubungan terus dengan Allah. Manakala, hubungan manusia secara horizontal pula melibatkan hubungan manusia sesama manusia dan alam.

Kajian oleh Mohd Yusof Hasan (2007:15) menyatakan pemikiran kebitaraan ialah pemikiran yang berhubung kait dengan perkembangaan otak manusia yang menjurus kepada kemahiran kecemerlangan, kegemilangan, kebestarian dan kepandaian. Pemikiran ini diwujudkan pada peringkat awal kejadian manusia lagi, iaitu daripada kandungan rahim hingga kepada umur kanak-kanak. Dalam agama Islam, ianya mementingkan asas kekeluargaan yang bermula daripada perkahwinan manusia, hubungan suami isteri, mengandung, penjagaan pendidikan asas semasa bayi dan pendidikan kanak-kanak. Oleh itu, penerapan pemikiran kebitaraan dalam karya sastera adalah untuk memperlihatkan dan menampilkan watak-watak yang berilmu pengetahuan, berketrampilan, berakhlak mulia dan bertanggungjawab supaya watak-watak yang dipaparkan dalam sesebuah karya dapat diketengahkan peranannya dalam menyelesaikan sesuatu konflik dan menjadi ikutan atau suri teladan kepada pembaca khususnya remaja.

Mohd Yusof Hasan (2007:10) menyatakan bahawa pemikiran kesaintifikan merupakan pemikiran yang bersifat logik dan saintifik yang membawa kepada kebenaran, kepastian, ketepatan dan kegunaan fakta dan angka. Dalam komunikasi sehari-hari antara manusia dalam penulisan dan pembacaan, pertuturan dan pendengaran, manusia perlu menggunakan ilmu logik. Logik ialah proses penakulan yang membawa kepada keputusan seperti idea, fakta atau keputusan. Ilmu logik ialah keseluruhan proses yang membawa kepada keputusan melalui penakulan yang berdasarkan bukti-bukti yang jelas dan konkrit. Oleh itu, melalui penghasilan sesebuah karya yang berteraskan pemikiran kesaintifikan, sesebuah karya haruslah mengemukakan latar belakang yang sebenar atau benar-benar wujud, menggunakan latar tempat yang bersesuaian seperti tempat-tempat yang indah dan permai, suasana yang aman, latar masa yang bersesuaian dengan peredaran zaman dan peristiwa yang benar-benar berlaku dalam kehidupan.

Mohd Yusof Hasan (2007:19) menjelaskan pemikiran kekreatifan merujuk kepada pemikiran bersifat literal yang membawa maksud inovatif, kreatif, idea baharu, kesenian, keindahan dan kecantikan. Objektif pemikiran ini adalah untuk memahami kepentingan pemikiran dan tempatnya dalam pemikiran manusia. Melalui pemikiran literal, terdapat teknik-teknik untuk mengenali pemikiran kreatif, seseorang dapat menambahkan kesedaran tentang cara memperkembangkannya dan mempergunakan kreativiti dalam diri dengan mempelajari perbezaan penting antara kaedah-kaedah penyelesaian masalah dan membuat sesuatu keputusan. Seseorang juga dapat mempelajari satu pendekatan sistematik untuk mencari peluang bagi semua peringkat pengurusan. Dalam kaitannya dengan penghasilan sesebuah karya sastera, seseorang pengarang yang mempunyai kemahiran pemikiran literal seharusnya menampilkan teknik penceritaan yang kreatif dan bermutu tinggi. Dalam teknik penulisan, ia merujuk kepada pembinaan plot cerita yang kompleks tetapi mudah untuk diikuti dan difahami oleh pembaca.

Pemikiran yang berteraskan keempat-empat pemikiran ini, iaitu pemikiran kerohanian, pemikiran kebitaraan, pemikiran kesaintifikan dan pemikiran kekreatifan mampu melahirkan pengarang dan karya yang unggul serta sesuai dengan keperluan semasa. Teori ini percaya bahawa sebuah masyarakat yang memiliki sifat pemikiran yang berteraskan $4 \mathrm{~K}$ mampu melahirkan pengarang dan karya yang bersifat sepadu dan komprehensif sesuai dengan keperluan asas manusia dengan gandingan empat perkara yang saling melengkapi antara satu sama lain, iaitu masyarakat, pengarang, karya dan pembaca.

Keempat-empat jenis pemikiran dalam teori ini dapat digambarkan seperti Rajah 1.

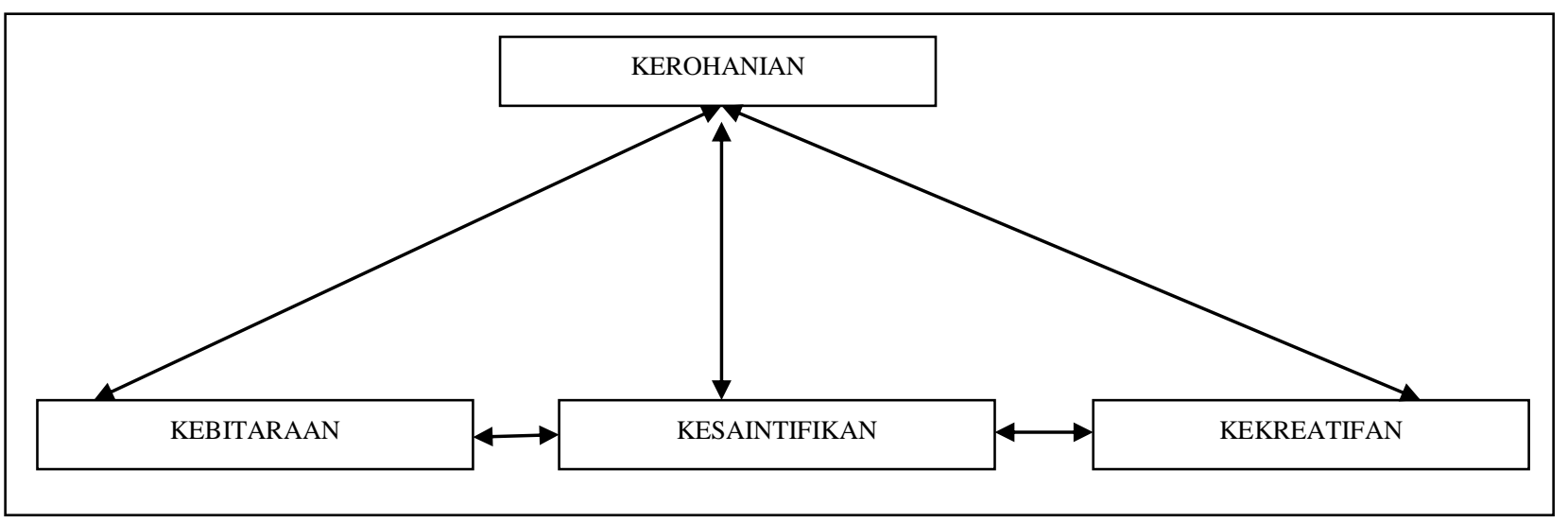

Rajah 1 Teori sistem pemikiran bersepadu (spb4k)

(Sumber: Diubahsuai daripada Mohd Yusuf Hasan, 2007)

Rumusannya dapat diringkaskan bahawa fokus pertama kajian ini ialah aspek pemikiran kerohanian akan dilihat pada peristiwaperistiwa dan perwatakan yang yang berlatarbelakangkan kehidupan Islam. Pemikiran kebitaraan pula akan dikaitkan dengan perwatakan watak-watak yang berfikir dan bertindak secara bitara dalam menghadapi sesuatu persoalan. Pemikiran kesaintifikan adalah berkaitan dengan peristiwa yang benar-benar berlaku dan pemikiran kekreatifan akan melihat kebolehan berfikir secara bijak dan kreatif 
menyelesaikan sesuatu permasalahan. (Mohd Yusof Hasan, 2007:14). Oleh itu, teori SPB4K ini mementingkan suatu rumusan yang bersifat holistik dengan menekankan seluruh keupayaan dalaman dan luaran seseorang manusia. Sekiranya para remaja dapat mengaplikasikan teori SPB4K dalam kehidupan seharian mereka, mereka akan berusaha dan bersedia mendepani cabaran peralihan zaman. Remaja yang mempunyai nilai kemanusiaan yang tinggi sebagaimana yang digarap dalam novel Leftenan Adnan Wira Bangsa karya Abdul Latip Bin Talib (2014) sudah pasti remaja akan berwatak inovatif berfikiran kritis, kreatif dan bersikap suka membuat penambahbaikan menerusi kelainan dengan memanfaatkan segala ruang dan peluang di sekeliling mereka. Teori ini percaya bahawa sebuah masyarakat yang memiliki sifat pemikiran yang berteraskan 4K mampu melahirkan pengarang dan karya yang bersifat sepadu dan komprehensif sesuai dengan keperluan asasi jasmani, empat perkara yang saling berkait rapat antara satu sama lain, iaitu masyarakat, pengarang, karya dan pembaca. Oleh hal yang demikian, keempat-empat pemikiran dalam Teori Sistem Pemikiran Bersepadu $4 \mathrm{~K}$ menitikberatkan empat jenis pemikiran yang berlainan, namun pemikiran tersebut saling memerlukan secara bersepadu.

\subsection{ANALISIS DAN DAPATAN KAJIAN}

\subsection{Analisis Pemikiran Pengarang}

Kemunculan novel Leftenan Adnan Bangsa karya Abdul Latip bin Talib ini sebagai teks kajian wajib bagi murid-murid tingkatan 4 dan tingkatan 5 calon SPM yang dalam lingkungan usia remaja 16 hingga 17 tahun dianggap satu anugerah kepada golongan pembaca khususnya remaja. Novel ini terpilih sebagai teks Komponen Sastera (KOMSAS) wajib Sukatan Pelajaran Bahasa Melayu bagi zon 2 di negeri Selangor, Negeri Sembilan, Wilayah Kuala Lumpur \& Wilayah Putrajaya bermula tahun 2015 dan telah diuji dalam peperiksaan Sijil Pelajaran Malaysia (SPM) bagi tahun 2016. Pemikiran pengarang yang menggunakan teori SPB4K digarap pula dengan nilai-nilai kemanusiaan yang tinggi diadun dengan pelbagai pengalaman memperlihatkan kekuatan daya kreatif yang sentiasa berkembang.

Dalam novel ini memaparkan kisah cinta akan negara seorang tokoh yang berjasa kepada tanah air bernama Adnan yang berani dan menunjukkan semangat keperwiraan yang tinggi. Adnan seorang tentera dan Sophia seorang guru, yang akhirnya berpisah dengan kematian Adnan di tangan tentera Jepun. Kisah bermula apabila Adnan telah terpilih menjadi rekrut dalam Pasukan Askar Melayu yang kemudiannya telah dinaikkan pengkat sebagai leftenan tentera Askar Melayu Diraja kerana kebijaksanaan mengetuai barisan tentera dan kebolehannya berbahasa Inggeris dengan baik. Beliau sanggup korbankan nyawanya dan sanggup berjauhan dengan Sophia isteri kesayangan juga anak-anak demi mempertahankan tanahair. Sophia yang dihantar balik ke kampung bersama anak mereka bersedih hati apabila mendapat berita kematian suaminya Adnan akhirnya telah berkahwin baru dengan seorang guru. Manakala ayah Adnan, Pak Saidi telah dibunuh oleh tentera Jepun yang masih tidak berpuas hati dengan kematian Adnan cuba untuk menghapuskan seluruh ahli keluarga Adnan. Seluruh keluarga Adnan terbunuh dalam cerita ini. Semoga semangat dan keberanian perwira Melayu ini yang terkadung banyak nilai kemanusiaan akan menjadi inspirasi kepada remaja hari ini bagi mencintai tanah air dan mempertahankan kemerdekaan negara ini.

Manfaat penelitian kajian SPB4K ini bagi mengembangkan wawasan pemikiran dalam bidang ilmiah dan sentiasa berkembang ke arah penerokaan ilmu baharu. Fikiran-fikiran yang ditimbulkan oleh pengarang terutamanya aspek-aspek berhubung kerohanian, kebitaraan, kesaintifikan dan kekreatifan menurut perspektif teori SPB4K. Pengarang cuba mengaplikasikan pengalaman yang diperoleh dalam kehidupan seharian menerusi penulisan karyanya bagi melahirkan insan yang yang mempunyai nilai keberanian, nilai bersemangat keperwiraan dan nilai baik hati dari aspek intelek dan akhlak iaitu nilai kemanusiaan yang tinggi sebagai pedoman hidup.

\subsubsection{Pemikiran Kerohaniaan}

Fokus pertama ialah aspek pemikiran kerohanian yang merupakan pemikiran berunsur keimanan dan keagamaan yang membawa manusia ke arah manusia yang soleh atau solehah. Menurut Mohd Yusof Hasan, (2007:34), pemikiran ini berkaitan dengan ketuhanan, keimanan, keagamaan, ketauhidan dan keesaan tuhan. Selain itu, pemikiran kerohanian ini juga merupakan pemikiran yang tinggi martabatnya, suci murni dan berhubung kait dengan unsur - unsur ghaib serta ketuhanan. Hubungan Allah dengan manusia merupakan hubungan dari aspek Hablumminallah. Allah sebagai pencipta dan manusia sebagai khalifah serta hanba-Nya di muka bumi ini. Pengkaji telah menemui beberapa nilai kemanusiaan di dalam penulisan kreatif pengarang novel ini yang ada kaitan dengan pemikiran kerohaniaan di dalam Teori SPB4K seterusnya mampu menjadi penggerak dalam membangunkan nilai kemanusiaan remaja. Dalam novel Leftenan Adnan Wira Bangsa (2014) jelas terbukti pengarang Abdul Latip bin Talib melukiskan pemikiran kerohanian, iaitu nilai kemanusiaan tanggungjawab dan nilai kemanusiaan percaya kepada Tuhan.

\subsubsection{Pemikiran Kerohanian-Nilai Kemanusiaan Tanggungjawab/Percaya kepada Tuhan}

Perkataan tanggungjawab didefinisikan sebagai kewajipan yang harus dilaksanakan oleh semua orang tidak kira lelaki atau perempuan mengikut fungsi masing-masing. Tanggungjawab juga ditakrifkan sebagai tugas atau perkara yang perlu dilakukan oleh individu yang sudah dibebankan syarak dan agama kepadanya. Hubungan Allah dengan manusia merupakan hubungan dari aspek hablumminallah. Allah sebagai pencipta dan manusia menjalankan kewajipan sebagai khalifah dan hambanya. Konteks ibadat menjadi fokus utama dalam hal ini. Abdul Rahman Mohd Aroff (1999:76) menjelaskan bahawa ibadah yang dilakukan dengan ikhlas dan sempurna membentuk sahsiah yang mulia dan beroleh pahala daripada Allah SWT. Dalam kajian novel Leftenan Adnan Wira bangsa (2014:11), dilukiskan gambaran pemikiran kerohanian dengan teknik pemerian berdasarkan petikan teks novel, Pak Saidi akan pulang ke rumah selepas menoreh.Selepas solat Zuhur, dia turun pula ke sawah. Perbualan dengan Pak Samad yang menggambarkan perwatakan Pak Saidi iaitu:-

"Saidi rajin orangnya. Lepas Solat Subuh dia sudah pergi menoreh. Kemudian turun pula ke sawah. Tapi budak-budak muda sekarang lebih suka membuang masa dengan perkara-perkara yang tidak berfaedah," sindir Pak Samad kepada Nordin. 


\begin{abstract}
..Selepas menunaikan solat Zuhur, Adnan duduk berteleku di atas sejadah. Dia berdoa memohon restu dan diberikan kekuatan penuh kusyuk. Dia juga berdoa memohon kesejahteraan buat semua ahli keluarganya. Selesai berdoa, dia duduk di pangkin.
\end{abstract}

(Leftenan Adnan Wira Bangsa, 2014:216)

Petikan ini jelas membuktikan bahawa Adnan seorang yang taat kepada Allah dan mengerjakan solat sebagai tuntutan agama Islam. Gambaran akhlak mulia Adnan sebagai orang Islam ini turut dijadikan sebagai teladan yang perlu diikuti oleh golongan remaja pembaca novel ini. Selain itu, terdapat juga hadis yang mewajibkan supaya manusia beribadat. Antaranya ialah Imam Ahmad meriwayatkan, bahawa Rasulullah S.A.W. pernah bersabda:-
Maksudnya:"Sesiapa yang menjaga solat, nescaya solat itu menjadi cahaya, pembela dan penyelamat di hari kiamat. Manakala mereka yang tidak menjaganya tidak akan mendapat cahaya, pembela dan penyelamat. Bahkan mereka akan diletakkan bersama-sama dengan Qarun, Firaun, Haman dan Ubay bin Khalaf."

Berdasarkan kepada ayat hadis tersebut, ia memberi petunjuk bahawa tujuan sebenar manusia diciptakan Allah S.W.T. adalah sematamata untuk beribadat kepada-Nya, yakni sentiasa mematuhi ajaran-Nya dan menjauhi larangan-Nya. Namun, setiap amalan dan perbuatan yang dibuat oleh seseorang itu mestilah mempunyai niat yang ikhlas dan mealkukannya semata-mata kerana Allah S.W.T. Menerusi novel ini, pengkaji mendapati Pak Saidi sentiasa mementingkan solat dan mendidik ahli keluarganya hidup dengan amalan syariat Islam. Adnan dan adik-adiknya dididik bersolat oleh ayah dan ibunya sejak mereka kecil lagi. Sifat inilah yang ingin digarap oleh pengarang kepada generasi pembaca khususnya golongan remaja agar menjadikan solat sebagai benteng akidah dan keutuhan agama Islam. Dengan bersolat akan terhindar kemaksiatan dan manusia akan sentiasa dalam perlindungan Allah S.W.T. Berdasarkan petikan teks perbualan Mak Milah ibu Adnan dengan Adnan pula yang menggambarkan pemikiran kerohanian yang taat kepada agama apabila Adnan bermimpi berlawan dengan raksasa seperti petikan berikut:-

\title{
"Astaghfirullah...Adnan mengigau rupanya. Patutlah terjerit-jerit dalam tidur. Itulah akibatnya tidur tidak baca bimillah. Bangun cepat, pergi mandi kemudian solat subuh” suruh ibunya.
}

(Leftenan Adnan Wira Bangsa, 2014:10)

Pengkaji mendapati bahawa aspek nilai kemanusiaan tanggungjawab manusia yang menjaga hubungan dengan Allah melalui bersolat dapat dilihat dengan jelas dalam novel ini. Watak Pak Saidi dan Adnan sentiasa menjaga waktu solatnya kerana solat merupakan tiang agama. Demikian juga dengan ibu Adnan sering menceritakan tentang kehebatan pahlawan Islam, Khalid al-Walid kepada Adnan tiga beradik sebelum tidur. Hala tuju yang ditetapkan oleh agama Islam kepada setiap penganutnya agar yakin dengan Islam dan bersolat mampu membentuk insan yang seimbang dalam aspek rohani, jasmani, intelek dan emosi sepertimana yang digarisi Falsafah Pendidikan Kebangsaan. Ini bertujuan untuk memastikan golongan remaja hari ini sentiasa berada pada landasan yang betul.

\subsubsection{Pemikiran Kerohanian - Nilai Kemanusiaan Ketabahan}

Pemikiran-pemikiran yang terdapat dalam novel ini jika ditinjau dan dianalisis dari aspek pemikiran kerohanian sememangnya banyak digambarkan melalui peristiwa - peristiwa yang berlaku. Selain itu, ianya dapat diungkapkan melalui perilaku watak - watak yang terdapat dalam novel ini yang menggambarkan nilai kemanusiaan ketabahan yang tinggi, contohnya seperti Adnan anak sulung Pak Saidi yang menghadapi pelbagai cabaran dan dugaan dalam menempuh kehidupan dalam mengejar cita-cita menjadi pahlawan negara sebagai pegawai tentera kerana dikatakan bahawa darah keluarganya daripada keturunan pahlawan Melayu terbilang Datuk Siamang Gagap yang menentang orang putih di Seri Menanti semasa Tanah Melayu dijajah oleh British. Pak Saidi sanggup menyembunyikan rahsia kepahlawanan keturunan keluarganya untuk mengelakkkan pandangan serong orang ramai terhadapnya dan Pak Saidi mempunyai nilai kemanusiaan ketabahan dalam menempu liku-liku kehidupannya. Hal ini dapat diungkapkan dalam petikan berikut:

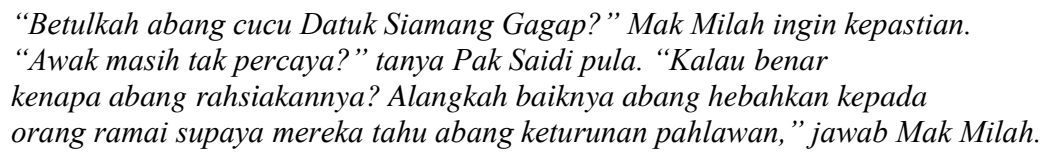

(Leftenan Adnan Wira Bangsa, 2014:7)

Sikap tabah dan sabar terdapat juga pada watak Adnan yang telah dijodohkan dengan Sophia seorang guru. Adnan tabah dan sabar kerana sanggup berjauhan dengan Sophia isterinya kerana tugasnya sebagai tentera yang tidak menentu. Secara fitrahnya manusia diciptakan Allah berpasang-pasangan, terdiri daripada jenis laki-laki dan perempuan, sehingga kehidupan manusia dapat berlangsung dan berkembang. Kenyataan yang dipaparkan dalam novel ini dijelaskan lagi dengan maksud firman Allah surah Ad-Zaariyat ayat 49 berikut:-

"Dan segala sesuatu Kami ciptakan berpasang-pasangan supaya kamu mengingatkan kebesaran Allah”. 
Seterusnya, sifat tawakal juga digambarkan oleh pengarang dalam diri Pak Saidi dan penduduk kampung yang mengadakan majlis solat hajat untuk mengelakkan sebarang kejadian serangan Jepun di kampung tersebut. Pak Saidi meminta isterinya Mak Milah membuat kuih untuk di bawa ke masjid pada malam itu. Hal ini terdapat dalam petikan teks novel seperti berikut:-

"Malam nanti ada solat hajat di masjid, sekarang telah heboh Jepun nak menyerang Tanah Melayu. Kita tak ada jalan untuk menghalang Jepun itu selain meminta perlindungan daripada Allah. Mudah-mudahn mereka tak datang ke kampung kita ini. Kita berdoa kepada Allah mudah-mudahan semuanya dalam keadaan selamat."kata Pak Saidi.

(Leftenan Adnan Wira Bangsa, 2014:215)

Menurut Abu Zakaria Ansari (2010), tawakkal ialah "keteguhan hati dalam menyerahkan urusan kepada orang lain". Sifat yang demikian itu terjadi sesudah timbul rasa percaya kepada orang yang diserahi urusan tadi. Ertinya ia betul-betul mempunyai sifat amanah (terpecaya). Sesorang yang mempunyai ilmu agama mampu menjawab segala persoalan yang dikemukakan kepadanya dan dengan ilmu yang ada bersamanya, seseorang itu dapat membezakan perkara yang betul atau perkara yang salah. Pengkaji mendapati watak Pak Saidi digambarkan cukup sempurna kerana berada dalam keadaan tenang walaupun dia sedar bahawa nyawa anak-anak kesayangannya dalam bahaya. Keadaan ini dapat dilihat melalui petika di bawah:-

"Milah, sebagai orang Islam kita wajib reda qada dan qadar. Bukan kita menentukan ajal maut, tapi Allah. Jika itu kehendak-Nya, kita tak boleh berbuat apa-apa," nasihat Pak Saidi kepada isterinya.

(Leftenan Adnan Wira Bangsa, 2014:216)

"Aku tengok, Leftenan Adnan itu tabah walaupu kehilangan adinya. Lebih-lebih lagi mayat adiknya terkubur di tengah laut," kata Koperal Yaakob sambil leka memerhatikan LeftenanAdnan yang sedang duduk di meja tulis.

(Leftenan Adnan Wira Bangsa, 2014:259)

Pengarang novel cuba memaparkan watak Pak Saidi yang begitu ideal mempunyai nilai kemanusiaan ketabahan yang sepatutnya ada pada setiap orang Islam. Konsep kematian yang diutarakan dalam novel membuktikan bahawa pengarang inginkan remaja hari ini memiliki nilai kemanusiaan ketabahan yang serupa seperti mana Pak Saidi dan Adnan. Keutuhan jiwa dan kekuatan iman dalam mendukung ilmu keagamaan yang tinggi dapat menyelesaikan pelbagai permasalahan kepincangan dalam hidup yang melibatkan isu kematian atau kehilangan orang tersayang. Dengan cara ini, generasi remaja diharapkan dapat berjiwa kental dan sedia mengharungi kehidupan dengan penuh semangat walau dalam keadaan genting sekalipun.

Satu kenyataan bahawa hidup manusia di dunia ini akan selalu berhadapan dengan situasi adakala bahagia adakala sengsara. Hidup ini ibarat putaran roda. Yang paling penting ialah bagaiman tindakan manusia dalam menghadapinya dan menerima situasi tersebut. Beliau harus menerapkan sikap sabar kerana ia sesuatu yang amat penting untuk dimiliki oleh setiap individu muslim. Ujian Allah dan cabaran yang mendatang haruslah dihadapi penuh kesabaran. Firman Allah SWT tentang keburukan dan kebaikan dalam kaitannya dengan kesabaran, dinyatakan dalam surah Al-Anbiya ayat 35 seperti maksud berikut:-

Setiap yang berjiwa akan merasakan mati. Kami akan menguji kamu

dengan keburukan dan kebaikan sebagai cubaan ( yang sebenar-benarnya).

Dan hanya kepada Kamilah kamu dikembalikan."

(Al-Quran, 2007:324)

\subsubsection{Pemikiran Kerohanian - Nilai Kemanusiaan Kesyukuran}

Watak Adnan yang dididik oleh ayahnya Pak Saidi sejak kecil dengan ilmu agama yang kuat seimbang dengan ilmu keduniaan kerana Adnan bersekolah di sekolah Inggeris walaupun mendapat tentangan hebat penduduk kampungnya. Kehidupan keluarga Adnan penuh liku, digambarkan tidak melupakan nilai keimanan, keluhuran sikap dan pemikiran untuk berjaya untuk mengubah kehidupannya. Hal ini dapat dibuktikan dengan perbualan Pak Saidi dan isterinya Mak Milah tentang harapannya dan sikap yang ada nilai kemanusiaan kesyukuran untuk membentuk kehidupan anak-anak mereka seperti petikan berikut:-

"Bersyukur kepada Tuhan kerana kita dikurniakan tiga orang anak lelaki yang sihat. Abang didik mereka supaya menjadi berani, kuat semangat dan tidak mudah menyerah kalah.”

(Leftenan Adnan Wira Bangsa, 2014:2)

Pengkaji dapat mengambil unsur nilai kemanusiaan bersyukur dalam novel yang dikaji dan diharapkan remaja hari ini mengamalkan prinsip yang sama. Amalan nilai bersyukur ini menjadikan kehidpan masyarakat khususnya golongan remapaja pembaca lebih tenang dan tidak menyalahkan orang lain dengan segala kejadian yang berlaku. Sikap bersyukur ini mendidik sesorang itu bersih jiwanya dan hidup lebih bermakna. Satu kenyataan bahawa hidup manusia di dunia ini akan selalu berhadapan dengan situasi adakala 
bahagia dan adakala sengsara. Hidup ini ibarat kitaran roda. Yang paling penting adalah bagaimana tindakan manusia dalam menghadapinya dan menerima situasi tersebut dalam keadaan mereka bersyukur.

\subsubsection{Pemikiran Kerohanian - Nilai Kemanusiaan Kasih Sayang}

Antara Pemikiran Kerohanian yang terdapat dalam novel Leftenan Adnan Wira Bangsa ini ialah penerapan nilai kemanusiaan kasih sayang. Nilai kemanusiaan kasih sayang merupakan sesuatu perasaan yang lahir secara semulajadi dalam diri seseorang individu yang terdapat dalam sesebuah masyarakat. Menurut Kamus Besar Bahasa Melayu Utusan (2002:800), menyatakan bahawa definisi kasih sayang ialah cinta kasih, belas kasihan, kasih mesra, perasaan kasih, perasaan cinta dan sayang, muhabat, hubah, percintaan dan pertemuan dengan hati. Kasih sayang amat penting bagi membina hubungan yang harmoni dan bahagia tanpa sebarang masalah.

Selain itu, menurut Ghazali Darussalam (2000:10), kasih sayang merupakan perasaan cinta dan kasih sayang yang mana merupakan jambatan untuk menegakkan keluarga yang harmoni dan bahagia. Dari situlah, akan wujudnya masyarakat yang kuat, mulia dan saling bertanggungjawab. Pengkaji mendapati, pengarang telah menerapkan nilai kasih sayang sesama manusia tanpa mengira darjat serta harta melalui watak dan perwatakan yang terdapat dalam novel ini. Hal ini bertepatan dengan teori SPB4K yang diperkenalkan oleh Mohd Yusof Hasan tentang Pemikiran Kerohanian dalam aspek nilai kemanusiaan kasih sayang.

Nilai kemanusiaan kasih sayang dapat dilihat melalui watak Pak Saidi yang mana kasih sayang terhadap anak-anaknya Adnan, Ahmad dan Amirullah. Berdasarkan petikan novel Leftenan Adanan Wira Bangsa, (2014:15) Pak Saidi disambut gembira oleh anakanaknya sebaik sahaja sampai di rumah. Satu persatu kepala anak-anaknya diusap dengan penuh kasih sayang. Hilang rasa penat sebaik pulang dari menoreh getah apabila melihat wajah-wajah buah hatinya itu. Pak Saidi berasa amat gembira dan bahagia dikurniakan tiga orang anak lelaki. Hal inilah yang dingin disampaikan mesej oleh pengarang bahawa golongan remaja hari ini bahawa ibu bapa remaja amat sayang kepada mereka dan remaja pembaca perlu sedar akan hubungan yang perlu terjalin antara manusia dengan penciptanya iaitu Tuhan.

Pak Saidi juga digambarkan sebaik bapa yang berjiwa besar kerana telah memberikan pendidikan terbaik dengan menghantar anak-anaknya ke sekolah Inggeris di pekan yang jauh dari rumah. Dia terpaksa mengayuh basikal seawal pagi untuk menghantar Adnan ke sekolah dan mengambil anaknya Adnan pulang dari sekolah setiap petang. Pak Saidi sanggup dicemuh oelh penduduk kampungnya kerana menghantar anak ke sekolah Inggeris. Tetapi Pak Saidi mempunyai nilai ketegasan dengan prinsipnya yang mementingkan pendidikan terbaik untuk anak-anaknya kerana rasa sayang yang menebal terhadap anak-anaknya. Mak Milah pula akibat terlalu rindu dan sayang akan anak-anaknya telah menjadi tidak waras dan akhirnya meninggal dunia apabila menerima berita bahawa anak-anak lelakinya telah terkorban dalam peperangan. Ibu ini menderita sehingga menemui ajalnya. Sinonim dengan "kasih ibu membawa ke syurga" dapat dilihat bahawa kasih sayang seorang ibu yang mendalam. Ini dapat kita lihat melalui petikan dibawah:-

Raungan kuat Mak Milah mengejutkan Sophia“Apa terjadi ayah?” Tanya Sophia kepada Pak Saidi. Mak

Milah sudah jatuh terjelepuk ke lantai tidak sedarkan diri.

"Ahamd, dia tak ada. "Suara Pak Saidi bergetar

"Sabar Saidi, ingat Allah, ini semua kehendak-Nya. ”Pak Karim menenangkan perasaan sahabatnya

(Leftenan Adnan Wira Bangsa, 2014:256-257)

Pengkaji mendapati, nilai kemanusiaan kasih sayang dapat juga lihat melalui watak Adnan, iaitu suami kepada Sophia, kerana kasih dan sayangnya pada Sophia tergambar melalui tindakan Adnan yang berusaha dengan pelbagai cara mengembirakan Sophia dan sanggup berpisah dengan Sophia untuk menghantar isteri dan anaknya pulang ke kampung demi keselamatan isteri dan anaknya daripada serangan tentera Jepun. Contoh petikan ialah:-

"Abang terpaksa menghantar Sophia dan anak-anak pulang ke kampung. Banyak kawan abang akan menghantar isteri masing-masing balik ke kampung,sudah kedengaran ura-ura Jepun mahu menyerang Singapura dan mereka mahu menjajah Tanah Melayu, " terang Adnan.

(Leftenan Adnan Wira Bangsa, 2014:158)

Berdasarkan petikan di atas, jelas membuktikan Adnan begitu sayang akan isteri dan anak-anaknya sehingga sanggup berjauhan demi keselamatan anak isterinya. Nilai kemanusiaan kasih sayang ini cuba dipaparkan oleh pengarang kepada remaja pembaca agar menghargai pengorbanan ibu bapa dan tokoh sejarah tanah air yang terdahulu. Mereka korbankan nyawa mereka demi mengekalkan kedaulatan tanah air tercinta. Nilai kemanusiaan kasih sayang beginilah yang ingin deterapkan ke dalam jiwa para remaja dan masyarakat pembaca agar wujud silaturrahim yang utuh dan saling mencintai sesama insan. Rasa kasih sayang ini perlu disemai sejak kecil lagi agar generasi akan datang hidup dalam harmoni dan pasti negara akan aman damai.

\subsubsection{Pemikiran Kerohanian - Nilai Kemanusiaan Keikhlasan}

Allah S.W.T mencipta manusia di muka bumi ini adalah untuk menjadi hambanya iaitu sentiasa mematuhi ajarannya dan menjauhi larangnya. Namun tujuan sebenar manusia diciptakan Allah adalah semata - mata untuk beribadat kepada Allah. Setiap amalan dan perbuatan yang dibuat oleh seseorang itu mestilah mempunyai niat yang ikhlas dan melakukan segala perbuatan semata - mata kerana Allah jelas membuktikan nilai kemanusiaan keikhlasan yang tinggi dalam jiwa pengamalnya. Menurut Abdul Rahman Mohd. Aroff (1999:76) pula, ibadah yang dilakukan dengan ikhlas dan sempurna dapat membentuk peribadi yang mulia dan mendapat pahala daripada Allah S.W.T. Sebagai contoh, sembahyang jika dilakukan dengan ikhlas dan sempurna dapat mencegah individu daripada melakukan kemungkaran serta kejahatan. 
Selanjutnya, Noormah Ismail (2001) pula menyatakan, Al-Quran dijadikan panduan dan pegangan hidup masyarakat untuk melahirkan insan yang berakhlak. Dari sudut pendidikan pula, jelaslah bahawa pentingnya individu memiliki ilmu dunia mahupun akhirat. Manakala dari sudut kemanusiaan dan sosiobudaya pula kepentingan sikap tolong - menolong, bekerjasama dan hormat menghormati dalam masyarakat.

Melalui novel ini, pengkaji mendapati, hubungan tuhan dengan manusia dapat dilihat melalui watak Pak Saidi yang menjaga adab dan patuh kepada ajaran agama. Sewaktu Pak Saidi menerima berita kematian anaknya Ahmad, Pak Saidi menguatkan semangat agar tidak terlalu mengikut perasaan. Pemergian anaknya satu ketentuan Ilahi. Dia pasrah. Suaranya bergetar ketika membaca surah Yassin. Sesekali dia memandang isterinya yang masih terbaring lesu. Hal ini dapat dilihat melalui petikan dibawah:-

"Sabar, Saidi. Ingatkan Allah. Ini semua kehendak-Nya". Pak Karim menenangkan perasaan sahabatnya. "Aku reda dengan pemergian Ahmad walaupun tanpa nisan. Sudah ditentukan Allah ajalnya begini. Lagi pun dia berjuang demi mempertahankan tanah air walaupun tanah tumpah darah kita ini ditawan oleh Jepun, "kata Pak Saidi sambil manrik nafas.

(Leftenan Adnan Wira Bangsa, 2014:257)

Selain itu, pengkaji berpendapat, sifat tawakal bertepatan dengan teori SPB4K iaitu berkaitan dengan konsep Pemikiran Kerohanian. Tawakal bermaksud berserah kepada Allah atas apa yang berlaku dan akan berlaku. Menurut Imam al-Ghazali (2010), tawakal atau tawakkal ialah menyandarkan kepada Allah S.W.T tatkala menghadapi suatu kepentingan, bersandar kepada-Nya dalam waktu kesukaran, teguh hati tatkala ditimpa bencana disertai jiwa yang tenang dan hati yang tenteram.

"Kita berdoalah semoga mereka semua selamat. Dan semoga roh mereka yang terkorban dirahati Allah. Dan andai mereka terkorban, kita terimalah dengan reda. Sesungguhnya orang yang menerima berita sebegini tergolong dalam golongan orang yang sabar," nasihat Imam Ahmad.

(Leftenan Adnan Wira Bangsa, 2014:257)

Menurut Abu Zakaria Ansari (2010), tawakkal ialah "keteguhan hati dalam menyerahkan urusan kepada orang lain". Sifat yang demikian itu terjadi sesudah timbul rasa percaya kepada orang yang diserahi urusan tadi. Ertinya, ia betul - betul mempunyai sifat amanah (terpercaya) terhadap apa yang diamanatkan dan ia dapat memberikan rasa aman terhadap orang yang memberikan amanat tersebut. Sifat tawakal ini digambarkan oleh pengarang dalam diri Pak Saidi dan Adnan. Keadaan ini dapat dilihat melalui tindakan Adnan iaitu abang kepada Ahmad yang menerima berita kematian Ahmad dengan tenang dan masih boleh meneruskan pekerjaannya di meja tempat bertugasnya untuk membuat perancangan licik menyerang musuh iaitu tentera Jepun. Dia tidak mahu dengan kematian adiknya membuatkan dia terus berduka. Hal ini dapat dibuktikan melalui petikan ini:-

"Aku tengok, Leftenan Adnan itu tabah walaupun kehilangan adiknya. Lebih-lebih lagi mayat adiknya terkubur di tengah laut," kata Koperal Yaakob sambil leka memerhati Leftenan Adnan yang sedang duduk di meja tulisnya.

(Leftenan Adnan Wira Bangsa, 2014:259)

Pengkaji mendapati pemikiran pengarang yang merungkai sifat Pak Saidi dan Adnan yang ideal itu perlu diteladani oleh golongan remaja pembaca agar mereka kuat semangat. Golongan remaja ini merupakan pelapis pemimpin negara yang akan menerajui negara pada masa hadapan. Sekiranya remaja goyah semangat, maka sukarlah untuk mereka memikirkan pembangunan negara dan langkah-langkah untuk mengatasi sebarang permasalahan negara. Benarlah kata pepatah Melayu, pemuda harapan bangsa, pemudi tiang negara.

\subsubsection{Pemikiran Kebitaraan}

Menurut Mohd Yusof Hasan (2001:30-31), Pemikiran Kebitaraan merupakan satu nilai mementingkan ilmu pengetahuan tentang kehebatan akal manusia. Pemikiran ini juga membantu kita untuk menjadi sarjana kerana pemikiran ini merupakan pemikiran kecemerlangan. Pemikiran Kebitaraan ini sebenarnya khusus untuk satu peringkat awal kejadian manusia, iaitu daripada kandungan rahim hingga kepada umur kanak - kanak. Hal yang sangat penting dalam pemikiran jenis ini ialah aspek - aspek kebijaksanaan dalam diri seseorang individu. Menurut Howard Gardner (1983), menganjurkan konsep Multiple Intelligence (MI) atau kepelbagaian kebijaksanaan yang melihat kebijaksanaan manusia daripada berbagai - bagai perspektif budaya, bahasa dan pemikiran tamadun manusia. Dengan mengambil beberapa contoh kehebatan manusia seperti Einsein, Woolf, Graham, Ghandi, Picasso, Freud dan Stravinsky, Gardner mengambil keputusan bahawa mereka itu semua berfikir untuk menyelesaikan masalah dan mereka mencipta alat - alat dalam media yang berbeza.

\subsubsection{Pemikiran Kebitaraan- Nilai Kemanusiaan Cintakan Ilmu}

Seseorang yang rajin membaca selalunya mempunyai ilmu agama yang mampu menjawab segala persoalan yang dikemukakan kepadanya dan dengan nilai mementingkan ilmu yang ada bersamanya, seseorang itu dapat membezakan perkara yang betul atau perkara yang salah. Pengkaji mendapati, Pak Saidi digambarkan oleh pengarang memiliki ilmu agama yang agak tinggi kerana beliau suka membaca dan menghebahkan kepada penduduk kampung sebagai satu cara penyampaian dakwah. Hal ini terbukti apabila Pak Saidi sering mengajar anak-anaknya solat berjemaah dan yakin dengan ilmu agama yang kukuh dia tidak perlu risau anak-anaknya bersekolah di sekolah Inggeris. Perbualannya bersama Pak Karim dan Lebai Pian telah mematahkan hujah Lebai Pian yang risau dengan tindakan Pak Saidi 
menghantar Adnan ke sekolah Inggeris, kerana khuatir Adnan akan terpengaruh dengan agama kristian yang dibawa oleh mubaligh kristian di sekolah Inggeris. Keadaan ini dapat dilihat melalui petikan dibawah:-

\begin{abstract}
"Nabi Muhammad SAW ada bersabda yang maksudnya,belajarlah kamu walau sampai ke negeri China. Sedangkan pada waktu itu China bukan beragama Islam. Hal ini bermakna kita boleh belajar dari orang yang bukan beragama Islam. Oleh itu, saya yakin tidak salah saya menghantar anak belajar di sekolah Inggeris."
\end{abstract}

\title{
(Leftenan Adnan Wira Bangsa, 2014:56)
}

Hasil daripada kajian novel Leftenan Adnan Wira Bangsa, pengkaji mendapati, terdapat beberapa aspek Pemikiran Kebitaraan yang digunakan oleh pengarang dalam karya ini. Hal ini sangat penting dalam pembangunan minda seseorang individu kerana pemikiran ini mementingkan nilai kebijaksanaan. Kebijaksanaan watak - watak dalam novel ini sangat terserlah dan boleh membantu khalayak pembaca khususnya golongan remaja untuk melakukan kebijaksanaan yang serupa. Adanan di sekolahnya digambarkan sebagai ikon bijaksana yang berusaha untuk belajar bahasa Inggeris di sekolah Inggeris dalam novel ini perlu diterjemahkan oleh pembaca sebagai pendorong semangat agar cinta akan ilmu dan berusaha untuk berjaya dalam kehidupan.

Adnan terkenal sebagai murid yang rajin dan pintar, malah sikap ringan tulangnya itu disenangi dalam kalangan teman dan guru sekolah. Oleh sebab sikapnya itu juga, di disayangi seorang guru bernama Cikgu Anderson. Adnan seorang murid yang mudah memahami apa-apa yang diajar terutama ketika di dalam kelasnya. Bagi guru Inggeris itu, walaupun usia muridnya itu masih muda, namun dia amat matang dan tegas menyatakan pendiriannya. Kebanyakan masanya dipenuhi dengan membaca dan mengulang kaji pelajaran. Tidak seperti murid lain, kecemerlangannya dalam bdiang akademik sudah terbukti apabila sentiasa mendapat tempat pertama di dalam kelas. Disebabkan hal itu, dia sering dijadikan contoh sehingga menimbulkan rasa cemburu dalam kalangan murid lain. Sememangnya benar, tiada jalan mudah untuk berjaya. Bermula dengan pendidikan awal seperti Adnan ini, akan melahirkan kejayaan cemerlang dalam kehidupan remaja pada masa hadapan. Oleh sebab itu, pemikiran pengarang dalam novel ini dianggap telah berjaya menggarap nilai kemanusiaan dalam novel untuk membangunkan nilai kemanusiaan remaja.

Melalui Pemikiran Kebitaraan yang diperkenalkan oleh Mohd Yusof Hasan (2001) dalam teori SPB4K, ianya selari dengan teori Multiple Intelligence yang menyentuh kebolehan interpersonal yang dikemukakan oleh Howard Gardner (1983). Menurut Kamus Dewan Bahasa dan Pustaka Edisi Keempat (2007), telah memberi definisi bitara sebagai tiada taranya dan hanya satu - satunya. Kebolehan interpersonal ini merujuk kepada hubungan seseorang individu dengan individu yang lain dan mampu bermesra dengan orang lain dengan bijaknya. Pengkaji mendapati pemikiran kebitaraan dalam SPB4K ini dapat dilihat menerusi watak-watak yang dipaparkan oleh penulis kreatif, di mana watak-watak tersebut digambarkan sebagai seorang yang bijak menangani pemasalahan yang dihadapi oleh dirinya mahupun individu lain yang berada di sekelilingnya. Antara watak-watak remaja yang digambarkan memiliki pemikiran kebitaraan ialah Adnan, Ahmad, Amirullah, Mamat dan Budin. Kebijaksanaan ini dapat dilihat melalui pemikiran Pak Saidi yang mana bijak menangkis tanggapan Lebai Pian terhadap pendidikan di sekolah Inggeris dari aspek Islam.

Walaupun Lebai Pian seorang alim di kampungnya, namun ia tidak menghalang Pak Saidi untuk memberi penerangan dan nasihat dengan mematahkah hujah Lebai Pian mengenai pendidikan di sekolah Inggeris dari perspektif ajaran Islam sebenarnya. Bagi Pak Saidi, kekerasan bukanlah jalan yang terbaik untuk menangani masalah yang terjadi di dalam dunia ini, sebaliknya jalan yang terbaik adalah dengan kembali kepada Al-Quran dan sunnah junjungan besar Rasullullah S.A.W. Pak Saidi bertindak merapatkan diri dengan Lebai Pian melalui cara berbual - bual dan tidak memarahi Lebai Pian atas tuduhan melulu perkara yang diucapkan oleh Lebai Pian.. Dengan cara ini, Pak Saidi dapat mengetahui isi hati Lebai Pian, Tok Penghulu dan pandangan masyarakat kampungnya tentang penerimaan pendidikan Inggeris. Keadaan ini dapat dilihat melalui perbualan Pak Saidi dengan Pak Karim seperti petikan berikut:-

"Buatlah yang tebaik Saidi, aku yakin dengan pendirian kau menghantar Adnan ke sekolah Inggeris.” Pak Karim memberi semangat kepada Pak Saidi."

(Leftenan Adnan Wira Bangsa, 2014:211-212)

Selain itu, melalui Pemikiran Kebitaraan yang dikemukakan oleh Mohd Yusof Hasan dalam teori SPB4K, ianya mempunyai hubungan dengan teori Multiple Intelligence yang mempunyai nilai ketegasan menyentuh kebolehan berbahasa atau kemahiran linguistik yang dikemukakan oleh Howard Gardner (1983). Pengkaji berpendapat, watak Adnan dan Pak Saidi sebagai watak-watak yang bijak serta mempunyai kebijaksanaan dalam kemahiran linguistik atau berbahas ketika menyampaikan maklumat secara kreatif dan saintifik berdasarkan kepada ilmu pengetahuan yang sedia ada. Hal ini dapat dilihat apabila Pak Saidi dapat menjawab sebarang persoalan dan kemusykilan yang diajukan kepadanya. Keadaan ini dapat dilihat apabila beliau berpesan kepada anaknya iaitu Adnan bahawa bidang pertanian jangan dipandang rendah kerana teknologi bidang pertanian semakin berkembang saban hari. Pak Saidi juga mahu Adnan menimba ilmu di sekolah Inggeris dan berharap Adnan dapat membawa balik pengetahuan tentang kepandaian orang putih di sekolah Inggeris untuk dimanfaatkan di negara ini kelak. Pak Saidi berhasrat lagi ingin mengubah imej dan pemikiran penduduk di kampung dan di negara ini yang dikaitkan dengan kepetingan menuntut ilmu baharu iaitu belajar di sekolah Inggeris agar tahu bahasa dan budaya penjajah Inggeris. Keadaan ini dapat dilihat melalui petikan dibawah:-

"Pak Lebai jangan bimbang sebab di sekolah Inggeris itu ada guru Melayu. Cikgu Nazri namanya. Dia orang yang taat kepada ajaran agama kita. Setiap hari Jumaat saya lihat di datang ke masjid bersolat Jumaat. Pada hari biasa juga dia datang solat berjemaah. Pernah Lebai bertanya kepaa Cikgu Nazri apa yang diajar di sekolah Inggeris itu? Anak-anak kaum China dan India juga ramai bersekolah di sekolah Inggeris itu. Adakah anak-anak kaum China dan kaum India itu menukar agama mereka? Saya pernah bertanya Ah Fat yang menghantar anaknya belajar di sekolah Inggeris. Saya telah membuat penyelidikan 
sendiri sebab itu saya menagambil keputusan untuk menghantar anak berlajar di sekolah Inggeris itu. ” Pak Saidi memberikan pandangannya semasa dia berada di kedai kopi Pak Samad.

\section{(Leftenan Adnan Wira Bangsa, 2014:56-57)}

Selain itu, Pemikiran Kebitaraan ini juga ditonjolkan oleh pengarang pada watak Pak Saidi dan Adnan. Pengkaji berpendapat bahawa, watak Pak Saidi juga mempunyai kebijaksanaan dalam menyatakan perkara yang tersirat yang mana melibatkan kemahiran linguistik. Watak Pak Saidi yang telah tua menggambarkan dirinya mempunyai banyak pengalaman hidup dan luas pemikirannya serta arif tentang kehidupan berkeluarga. Pak Saidi beranggapan sudah tiba masanya Adnan membina rumahtangganya selepas tamat persekolahannya. Oleh yang demikian, Pak Saidi bercadang untuk menjodohkan Adnan dengan Sophia. Kebijaksanaan Pak saidi tergambar apabila Pak Saidi menyatakan cadangannya itu secara kiasan terhadap Adnan. Keadaan ini menyebabkan Adnan tidak mengerti apakah perkara sebenarnya yang dimaksudkan oleh Pak saidi kepadanya dan meminta ibunya, Mak Milah untuk berterus terang. Kebijaksanaan Pak Saidi dalam mengungkapkan tujuannya kepada Adnan dapat dilihat melalui petikan dibawah:-

“Jarang ayah jumpa gadis yang bijak seperti Sophia,” puji ibunya. Adnan hanya mendiamkan diri.

"Banyak kali dia datang menolong kita, ayah tengok mungkin dia berminat dengan kamu."

(Leftenan Adnan Wira Bangsa, 2014:102-103)

Dari segi kebolehan intrapersonal yang dikemukakan oleh Howard Gardner dalam teori Multiple Intelligence yang juga selari dengan teori SPB4K yang diperkenalkan oleh Mohd Yusof Hasan, pengkaji mendapati, watak Adnan juga digambarkan sebagai seorang yang bijak dalam menyelesaikan masalah rakannya yang ingin bertumbuk dengan Adnan kerana ego dengan ejekan rakan-rakannya. Kebolehan intrapersonal atau kebolehan dalam diri merupakan cara seseorang untuk mengawal diri mengikut nilai, keadaan dan alam suasana dalam menyelesaikan masalah. Seseorang itu dapat membezakan keadaan dengan perasaan yang boleh membawa kepada gerak geri lakunya. Adnan bersetuju untuk menyertai pertandingan syarahan dalam bahasa Inggeris kerana tiada seorang pun rakan sekelasnya yang sanggup untuk menyahut cabaran Cikgu Nazri. Adnan diejek oleh rakan-rakan sekelasnya kerana Adnan tidak fasih berbahasa Inggeris tetapi sanggup untuk menyertai pertandingan syarahan bahasa Inggeris yang dianjurkan oleh pihak sekolah. Ini dinyatakan dalam petikan di bawah:-

"Tak ada seorang pun yang berminat?" Tanya Cikgu Nazri kepada murid-muridnya". "Kami tak pandai bersyarah cikgu, tambahan pula dalam bahasa Inggeris. "Kata Nizam yang berdiri di hadapan kelas. "Saya nak cuba cikgu," kata Adnan sambil mengangkat tangan kanannya.

(Leftenan Adnan Wira Bangsa, 2014:76)

Melalui novel ini, pengkaji mendapati, walaupun Leftenan Adnan berpangkat tinggi berbanding dengan, Koperal Yaakob namun dia tidak pernah merasakan pangkatnya yang tinggi itu sebagai satu penghalang untuk menerima idea daripada koperal Yaakob kepada permasalahan tersebut. Hal ini dapat dilihat melalui petikan berikut:-

“Maksud koperal, kita guna tenaga orang kampung?” tanya Leftenan Adnan inginkan kepastian.

"Kita perlu berusaha, tuan," tegas Koperal Yaakob. "Walau dengan apa cara sekalipun, asalkan tidak bercanggah dengan syariat islam dan yang paling penting mangsa dapat diselamatkan."

(Leftenan Adnan Wira Bangsa, 2014:18)

Pengkaji mendapati idea pemikiran kebitaraan yang digarap oleh pengarang ini diharapkan dapat dijadikan teladan oleh generasi remaja yang sentiasa belajar untuk berkomunikasi secara berkesan dengan sesiapa sahaja agar tidak dianggap kurang ajar. Kebijaksanaan dalam berkomunikasi dan menerima pendapat orang lain membuktikan ada unsur tolak ansur dan akhlak baik yang ingin dijana dalam diri golongan remaja dan masyarakat pembaca novel. Hal ini kerana setiap orang mempunyai kepandaian msing-masing yang tidak boleh dipandang rendah. Remaja pembaca disarankan agar mendengar pendapat orang lain dan menyaring, menyelidik serta menaakul sesuatu maklumat yang diterima sebelum menerima sesuatu perkara itu sebagai pilihan yang terbaik.

\subsubsection{Pemikiran Kesaintifikan}

Pemikiran Kesaintifikan ini merujuk kepada pemikiran yang saintifik, berfakta, berangka, tepat, objektif, tersurat, konkrit dan sebagainya. Pemikiran Kesaintifikan ini ialah sesuatu yang logik, mempunyai kebenaran, kepastian, ketepatan dan kesahihan. Pemikiran ini juga adalah pemikiran kepastian yang membawa ke arah manusia saintifik. Mengikut Irving M. Copi (1986), pemikiran logik ialah keseluruhan proses yang membawa kepada keputusan melalui penaakulan yang berdasarkan bukti - bukti yang jelas dan konkrit. Selain itu, Hulon Willis (1975) menyatakan bahawa ilmu logik atau Pemikiran Kesaintifikan merupakan sains penaakulan atau "The science of reasoning". Ilmu logik membantu kita melahirkan pemikiran yang jelas untuk penulisan atau pertuturan yang jitu.

\subsubsection{Pemikiran Kesaintifikan - Nilai kemanusiaan Keinsafan}

Hasil daripada kajian novel Leftenan Adnan Wira Bangsa, pengkaji mendapati, bahawa terdapat aspek Pemikiran Kesaintifikan yang digunakan oleh pengarang dalam karya ini juga dikaitkan dengan nilai kemanusiaan keinsafan. Hal ini sangat penting dalam pembangunan 
minda seseorang individu kerana pemikiran ini membawa individu untuk nilai berfikir secara saintifik, benar dan logik. Mengikut Roger Sperry (1981), otak kiri banyak dikaitkan dengan fungsi akademik yang terdiri dari kemampuan bercakap, kemampuan berbahasa, membaca tulisan, logik, angka, analisis, dan lain - lainnya. Biasanya ia diidentitikan dengan kecerdasan analitik atau intelek. Maksudnya, otak kiri kita ini banyak berkait dengan kemampuan matematik, analisis dan kemampuan berfikir secara sistematik. Cara kerja otak ini sangat rapi, terstruktur dan tersusun. Biasanya, otak kiri ini sangat bermanfaat digunakan untuk memahami hal - hal yang kompleks dan perlu pemikiran yang mengkhusus.

Melalui kajian yang dilakukan oleh pengkaji, pengkaji telah menemui beberapa Pemikiran Kesaintifikan yang telah diketengahkan oleh pengarang dalam novel Leftenan Adnan Wira Bangsa ini. Antaranya ialah Pemikiran Kesaintifikan ini yang membawa kepada penerapan nilai kemanusiaan keinsafan dapat dilihat dari segi penggunaan istilah saintifik bagi nama alatan ketenteraan yang banyak disebut di dalam karya. Ia dapat dilihat halaman 127 di dalam karya yang mana pengarang menggunakan istilah saintifik untuk mengungkapkan perlakuan pasukan latihan tentera dengan kehidupan di kem tentera seperti latihan berkawad."Buat dua barisan, gerak," teriak tentera. Sesudah itu, tentera berkenaan berdiri tegak, skuad memberi tabik hormat kepada pegawai tentera yang turut sama meyambut kedatangan mereka. Oleh yang demikian penggunaan istilah saintifik nama alatan ketenteraan seperti bayonet, senapang, dan digambarkan nama tempat kediaman tentera iaitu kawasan berek setingkat. Selain itu, digambarkan suasana kem pusat latihan tentera apabila Konstabel Daud membawa mereka ke setor untuk mengambil pakaian. Mereka diberikan dua pasang pakaian seragam dan kamejaT putih untuk dipakai di dalam kem. Selepas itu digunting rambut hampir kelihatan botak. Hal ini adalah bertepatan dengan Pemikiran Kesaintifikan kerana apa yang dihujahkan merupakan fakta, mempunyai ketepatan dan kesahihan.

Hal ini juga bertepatan dengan pendirian Mohd Yusof Hasan mengenai teori SPB4K yang menyatakan Pemikiran Kesaintifikan merupakan pemikiran logik, tepat, berdasarkan fakta dan angka, mempunyai hujah, objektif, dalil dan bukti. Pemikiran ini lahir dari hemisfera otak kiri yang bersifat sains, ilmiah, empirikal dan kritikal. Bukti yang menunjukkan penggunaan istilah saintifik bagi nama alatan tentera itu dapat dilihat melalui petikan dibawah:"pertempuran berakhir dengan menggunakan bayonet yang akhirnya askar Jepun berjaya mengalahkan
musuhnya. Jeneral Yamashita mengarahkan pasukan meriam membedil Lapangan Terbang Chepa"

(Leftenan Adnan Wira Bangsa, 2014:238)

Melalui kajian yang dilakukan oleh pengkaji, pengkaji telah menemui beberapa Pemikiran Kesaintifikan yang telah diketengahkan oleh pengarang dalam novel ini. Antaranya ialah Pemikiran Kesaintifikan ini dapat dilihat ialah dari segi penggunaan mikrochip yang digunakan oleh Jabatan Perhilitan untuk membanci jumlah sebenar hidupan liar. Microchip secara sederhana bererti chip iaitu bahan elektronik berupa semikonduktor yang diperbuat daripada silikon berukuran mikro. Ia sangat kecil sehingga dapat mencapai saiz $0.7 \mathrm{~mm}$ yang mana dapat menghantar frekuensi atau gelombang radio. Pemahaman ini sebagaimana beberapa pengertian microchip yang digaris berbagai status komersial, status pemuliharaan, dan status akademik.

Hal ini juga bertepatan dengan pendapat Roger Sperry (1981), yang menyatakan, individu yang menggunakan otak kiri, cenderung dan mempunyai kemampuan untuk menganalisis, berfikir secara sistematik memahami hal - hal yang kompleks dan perlu pemikiran yang mengkhusus. Secara tidak langsungnya, pengkaji berpendapat, pengarang telah mengambarkan peranan Jabatan Perhilitan mempunyai Pemikiran Kesaintifikan. Pemikiran Kesaintifikan yang digambarkan oleh pengarang pada Jabatan Perhilitan dalam penjagaan hidupan liar dapat dilihat melalui petikan dibawah:-

"askar-askar keturunan India daripada pasukan 1Hyderabad Infantry yang diketuai oleh Kolonel Hendrick dan juga pasukan 9th Batallion Heavy Anty-Aircraft of Hong Kong dan Singapore Royal Artilery, kata Kapten Fujimura."

(Leftenan Adnan Wira Bangsa, 2014:238)

Penggunaan fakta sejarah bagi novel ini menepati konsep Pemikiran Kesaintifikan yang dikemukakan oleh Mohd Yusof Hasan dalam teori SPB4K. Menurut Mohd Yusof Hassan (2007), bagi Pemikiran Kesaintifikan, sesebuah karya haruslah mengemukakan latar yang benar, tempat yang indah permai, suasana yang kondusif, masa yang sesuai, nada yang positif, zaman yang releven dan waktu yang jelas.

Hal ini juga bertepatan dengan pendapat Koh Young Hun (1993), yang memperlihatkan pemikiran Pramoedya dalam Tetralogi Bumi Manusia yang mengambil bentuk novel sejarah untuk memaparkan pemikiran pengarang berdasarkan kepada fakta - fakta sejarah zaman lampau negaranya. Isu yang didedahkan oleh Pramoedya dalam karya tersebut lebih penting untuk memperjelaskan dan menghidupkan fakta sejarah yang berkenaan. Pengkaji berpendapat, pengarang ingin menimbulkan fakta - fakta sejarah agar tidak luput ditelan zaman. Terdapat juga peribahasa Arab yang berbunyi, "Jika ingin membunuh sebuah pohon, racuni akarnya, jika ingin membunuh sesebuah bangsa, racuni sejarahnya”. Dari peribahasa Arab itu, dapat kita kita lihat, Sejarah merupakan suatu aspek yang penting dalam pembangunan sesebuah bangsa.

Sebagai usaha susulan dalam memahami sejarah, Kamus Dewan Bahasa dan Pustaka Edisi Keempat (2007), telah memberi definisi sejarah sebagai asal - usul, keturunan, salasilah, peristiwa yang benar - benar berlaku pada waktu yang lampau, kisah, riwayat, tambo, tawarikh dan kajian atau pengetahuan mengenai peristiwa yang telah berlaku. Penggunaan fakta sejarah iaitu pembunuhan Sir Henry Gurney yang membawa kepada pengisytiharan darurat dapat dilihat melalui petikan berikut:-

"Kawasan hutan ini banyak cerita anehnya. Jalan tar yang dinamakan Jalan Gap ini dibina awal 1900, penghubung di antara negeri Selangor dengan negeri Pahang. Asalnya jalan kuda yang digunakan pedagang-pedagang Melayu dari Ulu Pahang ke Ulu Selangor. Di sini jugalah Sir Henry Gurney ditembak mati penggans komunis pada tahun 1948 yang membawa kepada pengisytiharan darurat," cerita Sarjan Yusoff. Ghazali mendengar dengan teliti. 
Kajian ini mendapati penggunaan fakta yang tepat dalam Pemikiran Kesaintifikan yang dikemukakan oleh Mohd Yusof Hasan dalam teori SPB4K terdapat dalam novel ini sesuai dengan zaman dan budaya pemikiran remaja hari ini. Dengan adanya sains dan teknologi dan alat hubungan telekomunikasi hari ini sudah tentu segala maklumat yang diterima perlu cepat dan tepat. Maka remaja hari ini disaran agar menggunakan kemudahan yang canggih ini dengan bijak agar tidak menyalahgunakannya ke arah kejahatan. Pengetahuan tentang bidang pertanian dan ketenteraan yang dipaparkan dalam novel ini, dapat memberi penghayatan yang lebih baik dan remaja pembaca dapat menyelami dan mengadaptasikan keadaan yang tersebut.

\subsubsection{Pemikiran Kekreatifan}

Menurut Mohd. Yusof Hasan (2004: 43), Pemikiran Kekreatifan ialah sebuah pemikiran yang tersusun, sistematik dan berdasarkan kepada kaedah saintifik. Pemikiran ialah hasil daripada aktiviti otak, akal atau minda. Saintifik pula merupakan satu sistem atau susunan dalam proses pemikiran. Melalui pemikiran ini, terdapat teknik - teknik mengenai Pemikiran Kekreatifan. Seseorang dapat menambah kesedaran tentang cara memperkembangkan dan mempergunakan kreativiti dalam diri dengan mempelajari perbezaan penting antara kaedah - kaedah penyelesaian masalah dan pembuat keputusan. Seseorang individu juga dapat mempelajari satu pendekatan sistematik untuk mencari peluang bagi semua peringkat pengurusan. Menurut Edward de Bono (1967), pemikiran lateral atau Pemikiran Kekreatifan merupakan proses penggunaan minda untuk berfikiran logik tetapi dengan cara berbeza atau baru. Berfikiran lateral atau kreatif selalu disinonimkan dengan kreativiti, ia juga berbeza jika dibandingkan dengan pemikiran lurus (vertical thinking) yang bersifat tradisional. Namun ia perlu digabungkan untuk tujuan pengukuhan.

\subsubsection{Pemikiran Kekreatifan- Nilai Kemanusiaan Berdikari}

Hasil dapatan yang dilakukan daripada kajian terhadap novel Leftenan Adnan Wira Bangsa, pengkaji mendapati, bahawa terdapat aspek Pemikiran Kekreatifan yang digunakan oleh pengarang dalam karya ini. Menurut Roger Sperry (1981), Otak kanan merupakan tempat untuk perkembangan hal - hal yang bersifat artistik, kreativiti, perasaan, emosi, gaya bahasa, seni, irama musik, imaginasi, fantasi, warna, pengenalan diri dan orang lain, hubungan sosial dan pengembangan keperibadian.

Pengkaji berpendapat bahawa, Pemikiran Kekreatifan ini dapat dilihat melalui perwatakan Adnan yang digambarkan oleh pengarang sebagai watak yang kreatif dan berdikari. Hal ini dapat dilihat yang mana Adnan mempunyai bakat serta kemahiran dalam bidang seni persilatan dan berpidato yang cenderung menggunakan otak kanan. Seni pidato merupakan salah satu aktiviti penghasilan karya dalam bidang seni kreatif. Hasil karya pidato menyediakan landasan asas untuk berkomunikasi dalam pelbagai cara dan bidang. Biasanya, bahasa dalam pidato diolah untuk menyampaikan mesej kepada penonton. Penghasilan teks pidato bertujuan untuk menguji kebolehan berbahasa apatah lagi bahasa yang digunakan bahasa asing iaitu bahasa Inggeris. Bahasa dalam pidato juga mendekatkan kita dengan emosi, keintelektualan dan juga spiritual. Bahasa juga boleh menyatakan luahan emosi, intelektual dan spiritual manusia serta dapat mengembangkan kedua - dua minda dan semangat (spirit).

Justeru, bahasa sebagai satu cara menghargai pendapat dan pemikiran manusia. Kemahiran yang ada dalam diri Adnan yang merupakan seorang murid dan juga seorang guru bahasa Inggeris mengambarkan watak Adnan sebagai seorang yang kreatif dan sikap berdikarinya apabila bersungguh-sungguh dalam apa yang diusahakan. Kehebatan Adnan berpidato dalam bahasa Inggeris kerana semangat berdikarinya yang tinggi, bersungguh-sungguh berlatih telah menyebabkan Adnan menjuarai pertandingan pidato yang dianjurkan oleh sekolahnya dan dikagumi oleh warga sekolah. Hal ini terdapat pada petikan dibawah:-

Dia kembali kepada minatnya, tangannya pantas menggariskan warna pada kanvas. Merakamkan keindahan kampung dengan hati dan mata seninya. Seolah-olah kampungnya telah memberikan inspirasi yang begitu bernilai, tentang keindahan fajar subuh

(Leftenan Adnan Wira Bangsa, 2014:159-160)

Selain itu, melalui kajian yang dijalankan, pengkaji juga mendapati, Pemikiran Kekreatifan bukan sahaja terdapat pada watak yang dilakarkan oleh pengarang, malahan Pemikiran Kekreatifan ini juga terletak pada diri pengarang sendiri semasa melahirkan karya ini Hal ini dapat dilihat dari segi aspek kepengarangan atau aspek gaya bahasa yang digunakan oleh pengarang untuk menghidupkan cerita. Gaya bahasa memainkan peranan yang penting dalam penghasilan sesebuah karya sastera. Menurut Roger Sperry (1981), Otak kanan merupakan tempat untuk perkembangan hal - hal yang bersifat artistik, kreativiti, perasaan, emosi, gaya bahasa, seni, irama musik, imaginasi, fantasi, warna, pengenalan diri dan orang lain, hubungan sosial dan pengembangan keperibadian.

Oleh yang demikian, aspek gaya bahasa menepati Pemikiran Kekreatifan dan merupakan sesuatu perkara yang sangat dititikberatkan oleh seseorang pengarang. Kepentingan gaya bahasa adalah untuk mengindahkan lagi sesebuah karya serta menjamin agar pembaca lebih memahami karya tersebut. Terdapat pelbagai jenis gaya bahasa yang digunakan oleh penulis dalam menghasilkan sesebuah karya kreatif. Dalam novel Leftenan Adnan Wira Bangsa karya Abdul Latip bin Talib, beliau menerapkan penggunaan gaya bahasa yang mudah dan sesuai dengan pelajar supaya mudah difahami. Pemilihan kata atau diksi, penggunaan ayat dan gaya bahasa yang digunakan, sesuai dengan situasi yang digambarkan dalam karya Abdul Latip bin Talib.

Maka secara tidak langsung, sikap Adnan yang ditemui pengkaji sebagai individu yang dalam lingkungan usia remajanya ketika itu telah berjaya menepati aspek pemikiran kekreatifan yang digambarkan oleh pengarang. Bukan setakat berjaya dalam pelajarannya, Adnan juga kreatif dalam bidang pekerjaannya sebagai guru dan pegawai atasan tentera. Oleh sebab itu, Adnan terpilih dihantar ke London bertemu dengan Ratu England dan dianugerai set pakaian seragam tentera sebagai penghormatan atas komitmennya yang tinggi dalam bidang ketenteraan. Inilah yang ingin digambarkan oleh pengarang sebagai pembakar semangat kepada golongan remaja pembaca agar menjadi Adnan sebagai role model atau suri teladan.

Antara contoh gaya bahasa yang terdapat dalam karya ini yang menunjukkan Pemikiran Kekreatifan pengarang ialah gaya bahasa personifikasi. Menurut Nik Hassan Basri (2007), gaya bahasa personifikasi merupakan gaya bahasa perbandingan iaitu penginsanan atau pemberian ciri - ciri peribadi orang atau sifat - sifat manusia kepada sesuatu benda, binatang, tumbuh - tumbuhan, keadaan atau idea 
yang abstrak. Gaya bahasa jenis ini dapat dilihat melalui pemberian sifat manusia iaitu "menggigit" pada "dingin" dan perbuatan "menyambut" pada "pagi" yang datang. Hal ini dapat dilihat pada petikan pelbagai contoh yang berikut:-

..Embun pagi masih menitis dihujung daun. Hujan yang turun sepanjang malam menjadikan cuaca pagi itu sejuk. Kampung Sungai Ramal Luar begitu sepi sekali.Tidak lama kemudian, barulah matahari muncul dari balik bukit lalu memancarkan cahayanya menerangi perkampungan itu.

(Leftenan Adnan Wira Bangsa, 2014:8)

..Cuaca petang itu terang dan cerah. Mentari memancar terik. Pak Saidi duduk di beranda sambil otaknya ligat berfikir.

(Leftenan Adnan Wira Bangsa, 2014:21)

..Kalau orang Melayu masih tidak mahu berubah, maka selamanya akan dicucuk hidung.

(Leftenan Adnan Wira Bangsa, 2014:34)

..Kawasan persekitaran telah gelap dan kabus mula bangkit menyelubungi kawasan.

(Leftenan Adnan Wira Bangsa, 2014:67)

..Sayup-sayup kedengaran ayam jantan berkokok bersahut-sahutan memecah keheningan pagi..

(Leftenan Adnan Wira Bangsa, 2014:301)

Selain itu, pengkaji mendapati, pengarang juga menggunakan gaya bahasa hiperbola dalam novel Leftenan Adnan Wira Bangsa. Menurut Nik Hassan Basri (2007), gaya bahasa hiperbola merupakan salah satu daripada kelompok gaya bahasa pertentangan. Gaya bahasa hiperbola ini juga mengandungi kenyataan secara berlebih - lebihan atau secara melampau. Pengarang menggunakan gaya bahasa jenis ini kerana pengarang merasakan perlu melebih - lebihkan hal yang dibandingkan itu bagi mendapatkan perhatian yang lebih saksama daripada pembaca. Sebagai contohnya, pengarang ingin menyatakan masalah yang dihadapi oleh Mak Milah ibu Adnan dengan cara berlebih - lebihan bagi mengambarkan kehidupan Mak Milah yang penuh dengan rintangan dan cabaran ketika mendapat berita kematian Ahamd dan anak-anak lelakinya yang lain. Hal ini dapat dilihat melalui pelbagai contoh di bawah:-

...Dia juga merasai kehilangan walaupun dia sedar anaknya hanya berbakti kepada tanahair untuk mempertahankan negara daripada dijajah Jepun namun kasihnya menggunung menyebabkan Mak Milah hilang kewarasannya.

(Leftenan Adnan Wira Bangsa, 2014:194)

Suasana pagi itu begitu hening. Cuaca sejuk menusuk hingga ke tulang sum-sum. Kelihatan Askar Melayu yang tidak bertugas tidur-tidur ayam

(Leftenan Adnan Wira Bangsa, 2014:301)

Pengkaji mendapati, pengarang juga menggunakan gaya bahasa metafora. Menurut Nik Hassan Basri (2007), perkataan metafora ini berasal daripada bahasa Yunani. Metafora merujuk kepada gabungan daripada dua kata iaitu "meta" bermaksud memindahkan dan "pherein" bermakna membawa. Perkataan ini biasanya mengandungi satu kata konkrit dan satu kata abstrak dan ia bukannya membandingkan sesuatu secara terus. Penggunaan gaya bahasa metafora ini dapat dilihat dalam ayat yang berikut:-

“Selagi nyawa dikandung badan, kita pertahankan bumi tercinta, ”teriak Leftenan Adnan lagi.

(Leftenan Adnan Wira Bangsa, 2014:302)

Dia mahu semua anaknya keluar daripada kepompong pemikiran kolot bahawa anaknya harus mewarisi

pekerjaan orang tuanya.

(Leftenan Adnan Wira Bangsa, 2014:17)

Selain itu, pengkaji mendapati, terdapat juga gaya bahasa simile yang digunakan oleh pengarang dalam novel Leftenan Adnan Wira Bangsa. Menurut Nik Hassan Basri (2007), gaya bahasa simile merupakan perbandingan terus, iaitu membandingkan dua hal yang pada hakikatnya berlainan tetapi dengan sengaja dianggap sama. Perumpamaan ini secara jelas mengungkapkan sesuatu perbandingan atau persamaan dengan menggunakan kata seperti, bagai, laksana, umpama, ibarat, bak dan sebagainya. Penggunaan gaya bahasa ini dapat dilihat melalui petikan dibawah:- 
...Tembakan musuh semakin ganas bagai memuntahkan peluru tanpa henti

(Leftenan Adnan Wira Bangsa, 2014:318)

...Asyik makan tidur sahaja macam ular sawa.

(Leftenan Adnan Wira Bangsa, 2014:13)

Melalui novel Leftenan Adnan Wira Bangsa yang dikaji oleh pengkaji, pengkaji berpendapat, pengarang telah menggunakan bahasa asing dalam teknik penulisan beliau. Bahasa asing yang banyak digunakan oleh pengarang dalam karyanya ialah penggunaan bahasa Arab dan bahasa Inggeris. Penggunaan Bahasa Arab yang digunakan oleh pengarang adalah bertujuan untuk menggambarkan masyarakat tersebut mengamalkan agama Islam dalam kehidupan seharian mereka. Keadaan ini dapat dilihat dengan penggunaan bahasa bahasa Arab iaitu seperti perkataan Insya-Allah, Alhamdulillah, Rahmatullah, Assalammualaikum, Inalillahhi wa Innailaihirajiun, Qadak dan Qadar dalam percakapan diantara watak - watak. Hal ini dapat dilihat melalui petikan berikut:-

"Saya dah khatam baca Al-Quran. Tapi Ahamad dan Amarullah masih muqaddam... insya-Allah khatam juga nanti mereka tu," kata Adnan dengan bangga.

(Leftenan Adnan Wira Bangsa, 2014:29)

“Bagaimana dengan sekolah kamu Adnan?” tanya Pak Saidi.

"Alhamdulillah, ayah....

(Leftenan Adnan Wira Bangsa, 2014:)

“Assalamualaikum dan salam sejahtera...

(Leftenan Adnan Wira Bangsa, 2014:55)

...Terimalah qadak dan qadar Allah, Sophia."

(Leftenan Adnan Wira Bangsa, 2014:113)

"Inalillahhi wa Innailaihirajiun."

"Sabarlah, Saidi. Allah lebih sayangkannya."

(Leftenan Adnan Wira Bangsa, 2014:113)

...Ahmad pula kembali ke rahmatullah kerana terbunuh dalam serangan musuh negara di lautan."

(Leftenan Adnan Wira Bangsa, 2014: 122)

Penggunaan Bahasa Inggeris pula yang digunakan oleh pengarang adalah bertujuan untuk merujuk kepada nama sesuatu tempat atau penyakit. Keadaan ini dapat dilihat dengan penggunaan bahasa - bahasa Inggeris iaitu seperti perkataan good morning sir, Yes, dan no . Hal ini dapat dilihat melalui petikan berikut:-

"Sekarang aku baru dapat sebut beberapa patah perkataan. Antaranya, good morning, sir! Yes, no dan beberapa lagi"

(Leftenan Adnan Wira Bangsa, 2014:58)

Selain itu juga, pengkaji mendapati, pengarang ada menggunakan peribahasa bagi menyampaikan sesuatu dengan cara tersirat. Hal ini mengambarkan pengarang memiliki pemikiran kreatif dalam mengolah karyanya. Menurut Za'ba, peribahasa ialah susunan kata yang pendek dengan makna yang luas, mengandungi kebenaran, sedap didengar dan bijak perkataannya. Peribahasa juga merupakan ayat atau kelompok kata yang mempunyai susunan yang tetap dan mengandungi pengertian yang tertentu seperti bidal, pepatah, dan sebagainya. Peribahasa memainkan peranan yang penting dalam masyarakat di negara kita terutamanya di kalangan orang - orang Melayu. Peribahasa digunakan untuk menyampaikan sesuatu nasihat, teguran, atau ingatan secara kiasan atau sindiran. Antara contoh penggunaan peribahasa yang digunakan oleh pengarang dalam novel Leftenan Adnan Wira Bangsa dapat dilihat melalui petikan berikut:-

“Awalnya sampai,” sapa Adnan. Dia tahu Adnan ialah seorang pelajar yang amat pentingkan masa. Masa itu emas, kata Mamat tidak lama dahulu ketika dia lambat menghadiri kelas. Masa memang boleh menjadi emas. Mengikut peribahasa Arab pula masa umpama sebilah sebilah pedang tajam, boleh memenggal kepala jika kita lambat bertindak." 
...Apalagi yang boleh dikatakan, perkara sudah berlaku. Perahu sudah di air, pendayung di tangan.

“Malulah, mak. Mak bercakap macam perigi mencari timba pula,” dalih Sophia.

(Leftenan Adnan Wira Bangsa, 2014:60)

(Leftenan Adnan Wira Bangsa, 2014:102)

“Tapi mak...” Sophia kehilangan kata - kata. Adakah dia belum bersedia? Atau, bimbang pisang berbuah dua kali?...

(Leftenan Adnan Wira Bangsa, 2014:103)

Selain itu juga, pengkaji mendapati, pengarang ada menggunakan simpulan bahasa bagi menyampaikan sesuatu dengan cara tersirat. Menurut Za'ba, simpulan bahasa adalah kata - kata ringkas atau rangkaian perkataan yang dirumuskan dalam susunan tertentu yang membawa maksud tertentu. Maksudnya terdapat daripada apa yang tersirat atau tersembunyi bukan daripada yang tersurat atau nyata. Simpulan bahasa merupakan bentuk peribahasa yang paling ringkas dan biasanya terdiri daripada dua perkataan. Simpulan bahasa digunakan untuk menjelaskan lagi maksud sesuatu pengucapan dengan membawa erti yang mendalam. Kandungan maksud simpulan bahasa adalah berlainan daripada makna perkataan yang membentuknya.

Penggunaan simpulan bahasa yang tepat amat digalakkan samada dalam bentuk penulisan atau pertuturan seharian. Sesebuah cerita atau karangan akan lebih indah gaya bahasanya jika menggunakan simpulan bahasa yang betul. Kesimpulannya, simpulan bahasa mempunyai kehalusannya yang tersendiri di dalam menyampaikan maksud tertentu. Penggunaan gaya bahasa simpulan bahasa ini dapat dilihat melalui petikan d ibawah:-

....Keganasan tentera Jepun sering menjadi buah mulut orang ramai, malah pasukan tentera pun demikian terutama jika terpaksa bertugas di kawasan hutan dan pedalaman.

(Leftenan Adnan Wira Bangsa, 2014:19)

Sophia agak takut berbual dengan orang lain, yang seolah-olah memandang serong kepadanya. (Pandang Serong)

(Leftenan Adnan Wira Bangsa, 2014:16)

Buah fikiran dan kecekalan Adnan menghadapi hidup pada saat akhir menjadi pedoman.

(Leftenan Adnan Wira Bangsa, 2014:67)

Dia selalu pulang membawa buah tangan untuk anak dan isterinya.

(Leftenan Adnan Wira Bangsa, 2014:123)

Selain itu, pengkaji mendapati, terdapat juga gaya bahasa sinkof yang digunakan oleh pengarang dalam novel Leftenan Adnan Wira Bangsa. Menurut Nik Hassan Basri (2007), sinkof merupakan gaya bahasa penyirnaan, iaitu pengguguran huruf sisip atau suku kata sisip perkataan atau dengan menghilangkan huruf tengah atau suku kata tengah bagi perkataan atau pewujudan kata singkat atau ringkas, iaitu kata yang terhasil akibat penghilangan huruf atau suku kata. Penggunaan gaya bahasa ini dapat dilihat melalui petikan di bawah:-

“Cukup ke? Tak lapar nanti?” tanya Sophia kehairanan.

(Leftenan Adnan Wira Bangsa, 2014:145)

“Tok sahlah Si Samad tu tali barut Jepun. Sekarang apa tindakan kita?” tanya Leman

(Leftenan Adnan Wira Bangsa, 2014:290)

“Tak ada apa-apa," jawab Leftenan Adnan...

(Leftenan Adnan Wira Bangsa, 2014:287)

"Kau tidurlah, Adnan,"

(Leftenan Adnan Wira Bangsa, 2014:119)

Rumusan daripada hasil dapatan analisis gaya bahasa yang digarap oleh penulis, mempamerkan kematangan berkarya dan dapat mengetengahkan ilmu bahasa yang tinggi. Kebolehan pembaca mentafsir penggunaan bahasa dalam novel membuktikan pemikiran pengarang novel ini berjaya memartabatkan bahasa Melayu selaras dengan Falsafah Pendidikan Kebangsaan yang ingin menghasilkan pelajar-pelajar yang kreatif dan berinovasi. 


\subsection{KESIMPULAN}

Secara keseluruhannya, setelah dikaji dengan teliti serta ditelusuri aspek pemikiran pengarang dalam novel Leftenan Adnan Wira Bangsa karya Abdul Latip bin Talib ini mempunyai empat aspek pemikiran yang terdapat dalam teori SPB4K. Dengan adanya keseimbangan pemikiran seperti Pemikiran Kerohanian, Pemikiran Kebitaraan, Pemikiran Kesaintifikan dan juga Pemikiran Kekreatifan yang bertimbal balik dalam novel ini maka, novel ini dianggap baik. Empat aspek pemikiran ini bukan sahaja dapat dilihat melalui watak - watak yang terdapat dalam novel ini, malahan pemikiran ini juga dilihat pada diri pengarang itu sendiri. Melalui novel ini, pemikiran pengarang disalurkan kepada watak utama dalam novel ini iaitu Adnan yang mana mempunyai keempat - empat jenis aspek pemikiran yang saling bertimbal balik sehingga menjadikan watak Adnan sebagai watak yang hebat. Selain itu, penerapan empat aspek pemikiran ini juga dapat dilihat melalui peranan pengarang itu sendiri dalam mengolah karyanya supaya lebih bermutu dan mengaitkannya dengan aspek membangunkan nilai kemanusiaan remaja pembaca. Hal ini dapat dilihat dari segi pemikiran pengarang, teknik kepengarangan atau aspek gaya bahasa yang digunakan oleh pengarang untuk menghidupkan cerita. Oleh itu, novel Leftenan Adnan Wira Bangsa karya Abdul Latip bin Talib boleh dianggap novel yang baik kerana mengandungi empat aspek pemikiran. Hal ini menyebabkan novel ini sesuai digunakan untuk bahan pengajaran dan pembelajaran di sekolah dan telah dijadikan novel Komponen Sastera (KOMSAS) dalam mata pelajaran Bahasa Melayu, Tingkatan 4 Kurikulum Bersepadu Sekolah Menengah (KBSM).

\section{Rujukan}

A. Rahim Abdullah. (1995). Pemikiran Sasterawan Nusantara, Suatu Kajian Perbandingan. Kuala Lumpur: Dewan Bahasa dan Pustaka. A. Wahab Ali. (2000). Kritikan Estetik Sastera. Kuala Lumpur : Dewan Bahasa dan Pustaka.

Abdul Halim Ali. (2006). Ikhtisar Teori dan Kritikan Sastera Barat dan Malaysia. Tanjung Malim: Penerbit Profesional Baharu.

Abdul Latip Talib. (2014). Leftenan Adnan Wira Bangsa. Subang Jaya: Penerbitan Mika Cemerlang Sdn Bhd. PTS Media.

Abdul Rahman Mohd. Aroff. (1999). Pendidikan Moral. Teori Etika dan Amalan Moral. Selangor: Universiti Putra Malaysia.

Abu Razeen. (2009). Pembentukan Akhlak dan Sahsiah Ramaja Menurut Islam. Diperoleh Mei 19, 2014 daripada

http://aburazeen.blogspot.com/2009/09/pembentukan-akhlak-dan-sahsiah-remaja.html

Ali Ahmad. (1994). Pengantar Pengajaran Kesusasteraan. Kuala Lumpur: Utusan Publications \& Distributors Sdn.Bhd.

Al-Quran Darul Iman. (2007). Al-Quran Terjemahan: Resm Uthmani. Kuala Lumpur: Pustaka Darul Iman.

Ani Hj.Omar. (2016). Sastera Remaja di Malaysia Model Pembentukan Generasi Unggul. Tanjong Malim, Perak: Penerbit Mentari

Ani Hj. Omar. (2012). Esei dan Kritikan Kesusasteraan Melayu Alaf Baharu. Tanjong Malim, Perak: Penerbit Mentari.

Naffi Mat. (2013). Pemikiran Dharmawijaya Menterjemah Sosialisasi Masyarakat Desa dan Kota: Penerbit Universiti Pendidikan Sultan Idris, Tanjong Malim Perak

Aziah Tajudin dan Mohd. Fadzli Tajuid.(2013).Kamus Pelajar Bahasa Malaysia Edisi Kedua. Kuala Lumpur: Dewan Bahasa dan Pustaka.

Copi, Irving M. (1986). Introduction to Logic. London: Mac Millan.

Crow \& Crow. (1983). Psikologi Pendidikan Untuk Penguruan. Kuala Lumpur: Dewan Bahasa dan Pustaka.

de Bono Edward. (1993). Handbook for Positive Revolution. New York: Viking Penguin.

de Bono Edward. (1967). Serious Creativity. New York: Harper Business.

Engku Ahmad Zaki Engku Alwi.(2008).Apa Itu Islam?: Menerangkan Islam Secara Mudah dan Lengkap. Selangor: PTS Islamika.

Gardner, H. (1983). Frames of Mind: The Theory of Multiple Intelligences. London: Heinnmann.

H. B. Jassin .(1968). Tifa Penyair dan Daerahnya. Singapura: Malaya Publishing House Ltd.

Harun Jaafar. (2002). Teori dan Kritikan Sastera. Kuala Lumpur: Pustaka Sistem Pelajaran Sdn. Bhd.

Hashim Awang. (1988). Kritikan Kesusasteraan: Teori dan Penulisan. Kuala Lumpur: Dewan Bahasa dan Pustaka.

Hashim Awang. (1985). Mendekati Kesusasteraan Melayu. Petra Jaya: Fajar Bakti Sdn. Bhd.

Hashim Ismail.(2003). Pemikiran Kaum Muda di dalam Novel-novel Melayu sebelum Perang Dunia Kedua. Universiti Malaya.

Hulon, W. (1975). Logic, Language and Composition. Cambridge: Withrop Publisher.

John Lucas (1997). The Literature of Change, Studies in the Nineteenth Century Provincial Novel. New York: Harvester Wheatsheaf.

Junaidi Awang Besar. (2007). Kamus Dewan Edisi Keempat. Kuala Lumpur: Dewan Bahasa dan Pustaka.

Junaidi Awang Besar et al. (2012).Persepsi Politik Pengundi Belia Melayu Pasca Pilihan Raya Umum (PRU) 2008 di Malaysia. Jurnal Melayu, 9, $191-214$.

Kamarudin Hj Husin dan Siti Hajar Hj Abd Aziz. (1998). Pengajaran Melayu 4 Kesusasteraan dan Pengajaran Universiti Putra Malaysia. Selangor: Kumpulan Budiman Sdn.Bhd.

Kamarudin Haji Husain (1988). Kaedah Pengajaran Kesusasteraan. Petaling Jaya: Penerbit Fajar Bakti.

Kementerian Pelajaran Malaysia (2010). Kabus di Perbukitan. Kuala Lumpur: Dewan Bahasa dan Pustaka.

Koh Young Hun (1993). Pemikiran Pramoedya Ananta Toer dalam Novel- Novel Mutakhirnya. Universiti Malaya.

Mana Sikana (1998). Kritikan dan Pendekatan Kritikan Sastera Moden. Shah Alam: Penerbit Fajar Bakti Sdn.Bhd.

Masriayu Mustafa (2006). Pemikiran dalam Novel-novel Khadijah Hashim. Serdang: Universiti Putra Malaysia.

Mohd Gunawan Che Ab Aziz. (2003). Solat: Kejayaan Hakiki. Kuala Lumpur: Utusan Publications \& Distributors Sdn Bhd.

Mohd Ismail Mustari. (2007). Menjadi Belia Cemerlang. Kuala Lumpur: PTS Professional Publishing Sdn. Bhd.

Mohd Yusof Hasan (2007) Teori Pendidikan, Pemikiran Global. Tanjung Malim: Penerbit Universiti Pendidikan Sultan Idris.

Mohd Yusof Hasan. (2004). Pembinaan Paradigma Pemikiran Peradaban Melayu. Tanjong Malim: Penerbitan Universiti Pendidikan Sultan Idris.

Mohd Yusof Hasan (2001). Sistem Pemikiran Bersepadu 4L. Kuala Lumpur: Penerbit Fajar Bakti.

Mohd Yusof Hasan. (2000). Pemikiran Saintifik SPB4L. Petaling Jaya: Pearson Education Malaysia Sdn. Bhd.

Nik Hassan Basri Nik Ab.Kadir (2007). Komsas dan Tatabahasa Melayu Teras Pegangan Guru. Kuala Lumpur: Icon Region Sdn.Bhd.

Othman Puteh. (2001). Persediaan Menulis Novel. Kuala Lumpur : Dewan Bahasa dan Pustaka.

Rokeach. (1973). The Nature of Human Values. Illinois: Free Press.

Ruzaini Yahya (2001). Penghayatan Novel Terminal Tiga. Kuala Lumpur: Dewan Bahasa dan Pustaka.

S. Jaafar Husin. (1995). Penelitian Sastera-Metodologi dan Penerapan Teori. Kuala Lumpur: Dewan Bahasa dan Pustaka.

Shahabuddin Hashim, Mahani Razali dan Ramlah Jantan. (2003). Psikologi Pendidikan. Kuala Lumpur: PTS Publishing Sdn. Bhd.

Shahnon Ahmad. (1979). Gubahan Novel. Kuala Lumpur: Dewan Bahasa dan Pustaka.

Siti Aisyah Murad. (1996). Konsep dan Nilai dalam Kesusasteraan Melayu. Kuala Lumpur: Dewan Bahasa dan Pustaka.

Siti Emy Nurshafiera Mohd Safain. (2013). Penulisan Kreatif Dapat Menjana Minda dan Pendapatan Masyarakat. Tesis Saijana Muda, Tanjong Malim: Universiti Pendidikan Sultan Idris.

Siti Khariah Mohd Zubir. (2012). Penulisan Kreatif dalam Menjana Minda dan Sumber Pendapatan Belia. Malaysian Journal of Youth Studies (7), 157-167.

Siti Khariah Mohd Zubir. (2008). Citra Wanita dalam Novel Melayu. Tanjong Malim: Penerbit Universiti Pendidikan Sultan Idris.

Sohaimi Abdul Aziz. (2004). Novel dalam Kritikan. Pulau Pinang: Penerbit Universiti Sains Malaysia.

Syaikh Mohd Saifuddeen Shaikh Mohd Salleh dan Wan Roslili Abdul Majid. (2001). Belia dan Masyarakat. Kuala Lumpur: Institut Kefahaman Islam Malaysia.

Tam Yeow Kwei. (2006). Pendidikan Moral Konsep dan Pedagogi Pendidikan Guru. Kuala Lumpur: Kumpulan Budiman Sdn. Bhd. 
Yunus Hanis Syam. (2009). Sabar dan Syukur Bikin Hidup Lebih Bahagia. Demangan, Yogyakarta: Penerbit Mutiara Media. Zabidin Ismail .(2007). Pemikiran Politik Dalam Novel Ahmad Boestamam. Kuala Lumpur: Universiti Malaya.

Nik Abdul Aziz Nik Hassan. (2014). Penjelasan Ringkas Seminar Pemikiran Kassim Ahmad: Suatu Penilaian. Diperoleh Mei 19, 2014. $\mathrm{http} / / / \mathrm{www}$.themalaysianinsider.com/rencana/article/penjelasan-ringkas-seminar-pemikiran-kassim-ahmad-suatu-penilaian-nik 